\title{
Potential for managed aquifer recharge in southwestern Bangladesh based on social necessity and technical suitability
}

\author{
Floris Loys Naus ${ }^{1}$ (1) Paul Schot ${ }^{1}$ • Boris M. van Breukelen ${ }^{2} \cdot$ Kazi Matin Ahmed ${ }^{3}$ - Jasper Griffioen ${ }^{1,4}$
}

Received: 6 July 2020 / Accepted: 27 October 2020 / Published online: 11 November 2020

(C) The Author(s) 2020

\begin{abstract}
In southwestern Bangladesh, clean drinking water is scarce, since rainwater is only available during the monsoon, pond water is often bacteriologically polluted, and groundwater may exhibit high salinity and arsenic levels. Managed aquifer recharge (MAR) might potentially provide safe drinking water by storing abundant freshwater from the wet season in aquifers for year-round use. Regional potential for MAR was determined by combining assessments of (1) social necessity for MAR by mapping areas with insufficient drinking water of acceptable quality; (2) regional technical suitability by determining the (a) impact of density-driven flow on freshwater recovery efficiency, and (b) vulnerability of recovered water to mixing with contaminated groundwater. These assessments were based on the largest groundwater quality dataset compiled to date in southwestern Bangladesh, which contains 3,716 salinity and 827 arsenic measurements. The results show there is some mismatch between social necessity and technical suitability. In some northern areas, necessity is low because good quality groundwater is present and hence, despite the high technical suitability, potential for MAR is reduced. In other northern areas, groundwater with unsafe arsenic levels or brackish groundwater is likely used for drinking. There, MAR is a technically suitable and safer option. In southern areas, where saline groundwater is widespread and people consume bacterially unsafe pond water, the high groundwater salinity calls for careful evaluation of MAR design, for which this study presents practical guidelines. The approach developed may be useful for mapping MAR potential based on social necessity and technical suitability in other saline deltas worldwide.
\end{abstract}

Keywords Artificial recharge $\cdot$ Water supply $\cdot$ Bangladesh $\cdot$ Salt-water/fresh-water relations $\cdot$ Arsenic

\section{Introduction}

In southwestern Bangladesh, the provision of safe drinking water is not guaranteed, leading to the consumption of bacterially contaminated pond water (Knappett et al. 2011) and of

Supplementary Information The online version contains supplementary material available at https://doi.org/10.1007/s10040-02002264-1.

Floris Loys Naus

f.l.naus@uu.nl

1 Copernicus Institute of Sustainable Development, Utrecht University, Utrecht, The Netherlands

2 Department of Water Management, Delft University of Technology, Delft, The Netherlands

3 Department of Geology, Dhaka University, Dhaka, Bangladesh

4 TNO Geological Survey of the Netherlands, Utrecht, The Netherlands shallow groundwater with potentially high levels of arsenic and salinity (Ayers et al. 2016; Harvey et al. 2002; Naus et al. 2019a; b; Nickson et al. 1998; Flanagan et al. 2012; Khan et al. 2014). Overcoming consumption from these unsafe drinking water sources is directly linked to achieving Sustainable Development Goal 6 (SDG6), to 'Ensure availability and sustainable management of water and sanitation for all' (UN 2015).

One valuable technology for the provision of drinking water is managed aquifer recharge (MAR). It has been applied in different areas of the world to provide year-round drinking water access and to improve the drinking water quality (Dillon 2005; Maliva et al. 2006; Sprenger et al. 2017; Stefan and Ansems 2018). MAR stores water in the subsurface in times of abundant availability (e.g. the Monsoon) and retrieves it in times of need (e.g. the dry season). During the underground storage, the water is protected from surface pollution, for example due to tropical cyclones. Efforts to achieve SDG6 in southwestern Bangladesh (Satkhira, Khulna and Bagerhat districts; Fig. 1) have been made by piloting MAR 
Fig. 1 The physiography of the study area in southwestern Bangladesh

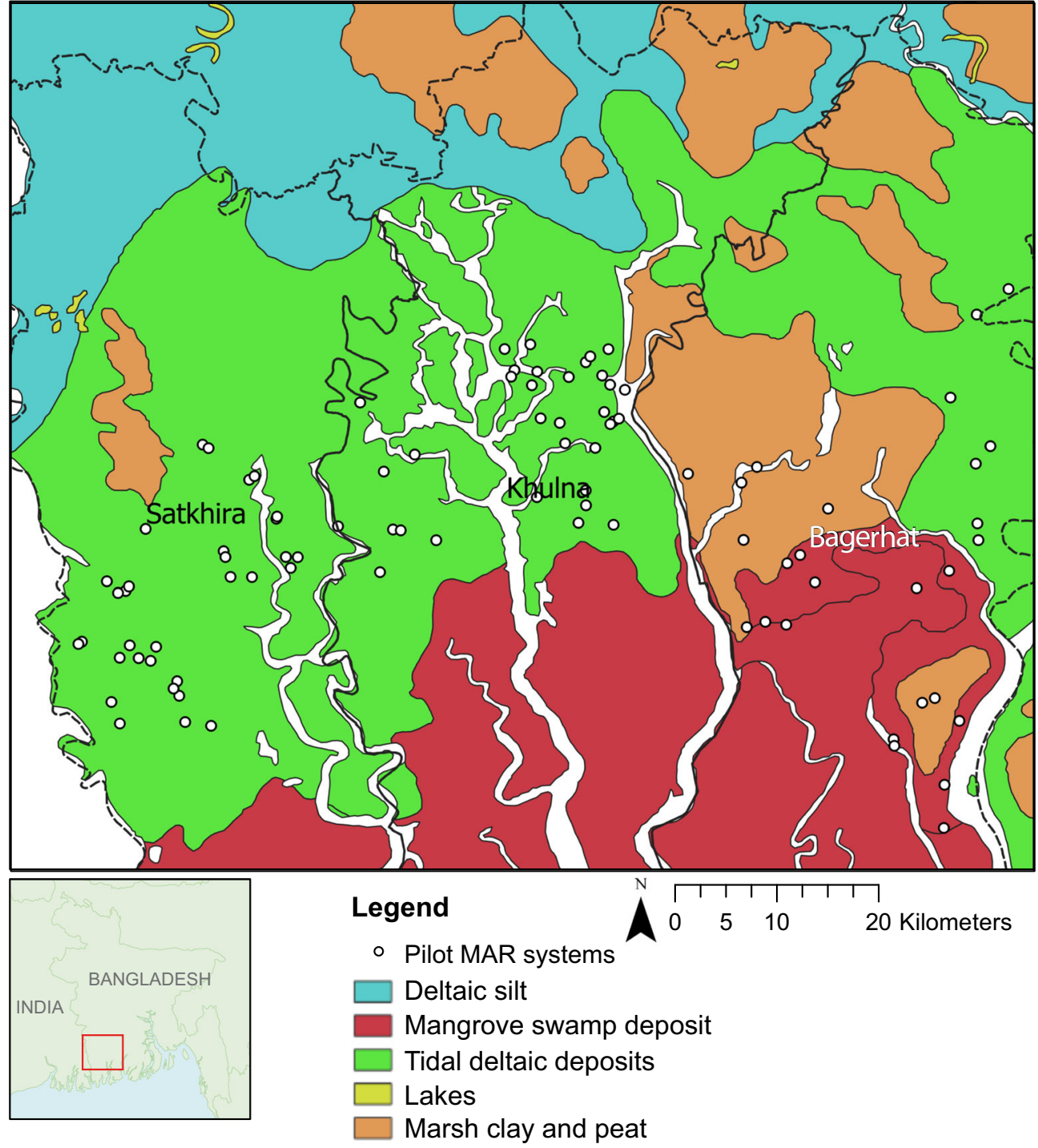

in the form of 99 small-scale community-run systems that use sand-filtered pond water as source. However, an evaluation of the initial 13 MAR sites showed that they do not always perform well technically. While recovery of freshwater was achieved at 11 sites, recovery efficiencies ranged from 5 to $40 \%$, and arsenic concentrations in recovered water was $>50 \mu \mathrm{g} / \mathrm{L}$ at six sites (Sultana et al. 2015). Further, it is simplistic to assume that MAR is necessary throughout southwestern Bangladesh (Peters et al. 2019; Naus et al. 2020). People may prefer the drinking water options already available (like rainwater harvesting, pond sand filters, and tube wells) rather than new MAR systems, even though the existing options have some limitations (they are not always available throughout the year or throughout the region). To determine the necessity for MAR it is thus essential to assess its benefits compared to existing water options. As a result of the aforementioned reasons, an ex-ante evaluation of the potential for MAR throughout the region is required in order to develop an implementation strategy for MAR in southwestern Bangladesh.

MAR suitability mapping or MAR site selection has previously been performed in various regions in the world with a focus on assessing the technical suitability of locations (Rahman et al. 2012; Ghayoumian et al. 2007; Kallali et al. 2007; Brown et al. 2005; Chowdhury et al. 2009; Russo et al. 2015; Zuurbier et al. 2013). Most of these studies assessed the potential applicability of MAR in terms of potential for aquifer recharge via spreading basins by examining natural conditions, including surface characteristics such as soil permeability, land cover and surface slope, as well as subsurface conditions such as aquifer transmissivity and storage capacity, and the quality of the native groundwater (Rahman et al. 2012; Ghayoumian et al. 2007; Brown et al. 2005; Chowdhury et al. 2009; Kallali et al. 2007; Russo et al. 2015). In some cases, other parameters were included: for example, parameters related to economic viability such as distance to the water 
source (Kallali et al. 2007). Standard practice for the site selection is to use expert judgement to interpret and combine the chosen parameters for an estimation of the site's suitability for MAR (Rahman et al. 2012; Ghayoumian et al. 2007; Kallali et al. 2007; Brown et al. 2005; Chowdhury et al. 2009; Russo et al. 2015).

In southwestern Bangladesh, the subsurface is characterised by a clayey confining top layer overlying sandy aquifers (Mukherjee et al. 2009). As a consequence, MAR systems must use injection wells, and though surface conditions limit where MAR systems can be sited, they do not necessarily control their performance. Instead, the performance is mostly determined by hydrogeological conditions such as groundwater quality and groundwater flow velocity. Technical suitability mapping for MAR systems that utilise injection and extraction wells calls for an assessment based on these aforementioned hydrogeological conditions. However, such assessments have only rarely been conducted, or been validated by comparing the assessment results with actual results of implemented MAR systems (Zuurbier et al. 2013).

The sites for the 99 pilot MAR systems in southwestern Bangladesh (Fig. 1) were selected on a case-by-case basis, based on prerequisites such as a suitable source for infiltration water, the lack of nearby tube wells tapping fresh groundwater, and the presence of a suitable aquifer confirmed by test drillings (Acacia Water 2014a; Hasan et al. 2018). On a regional scale, potential for MAR systems remains largely unknown. This study, therefore, sets out to comprehensively evaluate the MAR potential at a regional scale in southwestern Bangladesh by combining (1) an assessment of the spatially varying necessity for MAR, and (2) an assessment of the spatially varying technical suitability for MAR.

\section{Study area}

The study area consists of Satkhira, Khulna and Bagerhat districts (Fig. 1) and is characterized by tidal deltaic deposits and marsh deposits of clay and peat. Rainfall in the region is around 2,500 $\mathrm{mm}$ a year, with most rain falling in the monsoon season from July to October. The monsoon season is followed by a dry winter from October-March and a hot summer from March-June. There are many tidal rivers throughout the region that are fresh in the wet season but become saline in the dry season (Bhuiyan and Dutta 2012). The salinity of the tidal rivers is expected to increase under climate change scenarios (Zaman et al. 2017), and seawater flooding is expected to increase due to an increase in tropical storms with associated storm surges.

The region is predominantly rural, with about $80 \%$ of the 5.8 million people living in rural areas (Bangladesh Bureau of Statistics 2011). People mostly live in villages with trees usually on slightly higher elevated land than the surrounding areas and located in between the agricultural fields and aquaculture ponds. The livelihoods of the people are vulnerable to multiple stressors that may impact food and water security (Shameem et al. 2014). Borgomeo et al. (2018) speaks of a poverty trap, due to the interaction of flooding, salinity, agricultural gains and income.

\section{Methodology}

The approach of this study to determine MAR potential comprises the combination of two assessments. Figure 2 shows the approach schematically. The first assessment focussed on the spatially varying social necessity for MAR by examining limitations to the currently available drinking water options throughout the region, including the lack of good quality groundwater. The second assessment focussed on the technical suitability of the region for MAR systems, investigating (1) constraints for the construction of MAR systems and (2) using data on hydrological conditions to calculate the expected technical performance of the MAR systems. These two assessments were combined using GIS overlays to reveal the potential for MAR systems throughout the southwestern region of Bangladesh (Fig. 1). In both assessments, groundwater quality information regarding salinity and arsenic concentrations played an important role (Fig. 2). Therefore, the methodology starts with a description of how the regional groundwater quality was characterised.

\section{Regional characterisation of groundwater quality}

Groundwater was introduced as drinking water source in Bangladesh in the 1960s to prevent pond water being used as drinking water. However, it was found in the 1990s that in large parts of Bangladesh, including the southwest, groundwater is contaminated with arsenic to a depth of approximately $100 \mathrm{~m}$ (Nickson et al. 1998; Harvey et al. 2002; BGS and DPHE 2001; Fendorf et al. 2010). In southwestern Bangladesh, both the shallow and deep groundwater can additionally be brackish or saline (Ayers et al. 2016; Rahman et al. 2018; Naus et al. 2019a; b). Recently, local areas were found where hydrogeological conditions result in occurrences of fresh groundwater (Naus et al. 2019a; b).

\section{Data collection and data mining}

To characterise the groundwater quality in terms of salinity, a comprehensive database was compiled from data from previous studies and unpublished data collected during multiple fieldwork campaigns between November 2015 and September 2018 further described in Naus et al. (2019a, b). 
Fig. 2 Methodological framework to determine potential for MAR, combining spatial distributions of social necessity and technical hydrogeological feasibility. The ' $\mathrm{D}$ value' is a dimensionless indicator for the impact of density-driven flow (Bakker 2010)

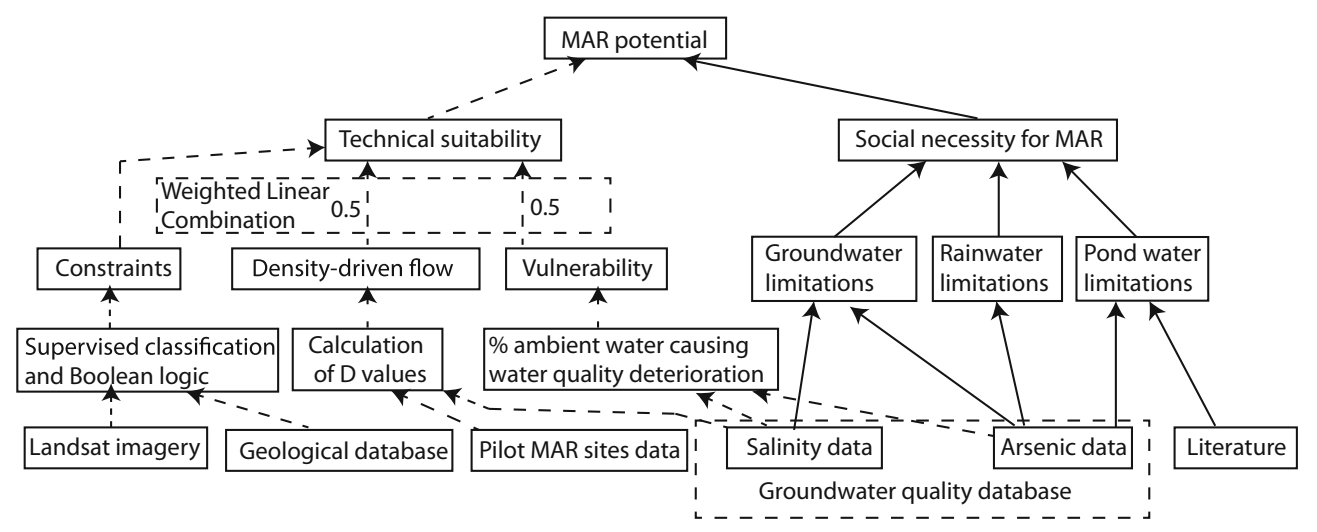

This database can be found in the electronic supplementary material (ESM).

For salinity, 2,440 shallow ( $<60 \mathrm{~m}$ deep) electrical conductivity (EC) measurements from the database of Naus et al. (2019b) were used, supplemented with 183 intermediate deep $(60-100 \mathrm{~m})$ and 715 deep $(>100 \mathrm{~m})$ previously unpublished groundwater EC measurements, and with 106 intermediate deep $(60-100 \mathrm{~m})$ and 72 deep $(>100 \mathrm{~m})$ groundwater EC measurements from the Bangladesh Water Development Board (BWDB) (2013) and from a dataset received from Vanderbilt University. Additionally, sodium (Na) data from the British Geological Survey (BGS) and Department of Public Health Engineering (DPHE) (BGS and DPHE 2001) were converted into $\mathrm{EC}$ values, mainly to fill in the areas with a few EC measurements in the northern parts of the region. For the conversion, the concentration of Na was first assumed to be about equal to $\mathrm{Cl}$ on a molar basis, and then converted to EC based on the correlations from Naus et al. (2019b), i.e. EC $(\mathrm{mS} / \mathrm{cm})=0.0022 \times \mathrm{Cl}(\mathrm{mg} / \mathrm{L})+1.134\left(R^{2}=0.84\right)$. This yielded an additional 146 shallow, 14 intermediate deep and 40 deep data points for salinity in the region, resulting in totals of 2586 shallow, 303 intermediate deep and 827 deep groundwater data points.

For arsenic, the database was constructed from data from previous studies (Ayers et al. 2016; BGS and DPHE 2001; BWDB 2013) and from data collected during the fieldwork campaigns described in Naus et al. (2019a, b). During the fieldwork campaigns, groundwater arsenic was measured with Hach field test kits (Hach company, USA) at 136 locations, and at 295 locations by taking samples after filtering through a $0.45-\mu \mathrm{m}$ membrane and storing them in $15-\mathrm{ml}$ polyethylene tubes for analysis in the lab with an ICP-MS. In total, the arsenic database consisted of 812 shallow $(<60 \mathrm{~m})$ and 52 intermediate deep (60-100 m) measurements.

\section{Spatial mapping of salinity and arsenic}

To arrive at continuous regional groundwater quality maps, the salinity and arsenic data were interpolated using ordinary Kriging. For the Kriging, a spherical variogram model was used that took the eight nearest measurements into account, which, after trial and error, provided a good balance between sensitivity to local variation and sensitivity to data further away. The resulting grid consisted of cells of $30 \times 30 \mathrm{~m}$. The Kriging maps have as an advantage that they provide a regional overview of the water quality data, but a disadvantage in that they do not yield accurate predictions of the local variation in groundwater quality. For the technical suitability assessment, only groundwater within manual drilling range was considered (Acacia Water 2014a), so Kriging for arsenic and salinity was applied on the data for shallow groundwater $(0$ $60 \mathrm{~m})$.

For the necessity assessment, the intermediate deep (60$100 \mathrm{~m}$ deep) and deep groundwater $(>100 \mathrm{~m})$ are also relevant in addition to the shallow groundwater, as both shallow and deep tube wells may be employed for drinking water supply. Therefore, additional Kriging was applied to the salinity data for intermediate deep groundwater $(60-100 \mathrm{~m})$ and separately for deep groundwater $(>100 \mathrm{~m})$. Unfortunately, there were not enough data for arsenic to be able to apply Kriging for the shallow groundwater separately from intermediate deep groundwater, so for the necessity assessment Kriging was applied for arsenic across the whole $0-100 \mathrm{~m}$ depth range. There were no large spatial differences between the arsenic Kriging maps over these two depth ranges. As few data were available on the arsenic content of the deep groundwater, Kriging for arsenic was not possible. Although arsenic may rarely occur in groundwater deeper than $100 \mathrm{~m}$, it is mostly absent in deep groundwater (BGS and DPHE 2001; Fendorf et al. 2010). Therefore, use of deep (>100 m) groundwater for drinking water was assumed to not be limited by arsenic.

\section{Assessment of the social necessity for MAR}

A necessity for MAR is deemed when the currently used drinking water options are unsafe according to drinking water standards or are temporally insufficiently available or are spatially unavailable. The study focused on the three most frequently used drinking water sources in the region, namely rainwater, pond water and groundwater, though there may 
also be other less frequently used safe drinking water options. Rules for mapping the necessity for MAR were formulated by reviewing the existing literature.

Rainwater is generally accepted to be of good quality (Peters et al. 2019; Naus et al. 2020). It can be collected everywhere in the region; however, the seasonality of rainfall causes it to only be temporally available (Benneyworth et al. 2016; Chowdhury 2010; Peters et al. 2019; Sharma et al. 2010). Consequently, most people who use rainwater in the monsoon season resort to a different option in the dry season such as pond water (Naus et al. 2020). Larger storage tanks could help overcome the seasonality of rainwater as a drinking water source, but storing rainwater is challenging, as the storage tanks can be bulky and costly, and the quality of the stored rainwater can deteriorate over time and can be contaminated during monsoon flooding (Islam et al. 2010; Despins et al. 2009; Dobrowsky et al. 2014). It was therefore assumed that the current usage of rainwater is only feasible for the local population in the wet season, and that there is still a need for MAR in the dry season.

Pond water is the traditional drinking water option in Bangladesh and is available throughout the region (Kränzlin 2000). The ponds are recharged by rainwater during the monsoon, and the use of pond water is seasonally limited for those ponds that run dry during the dry season. Pond water is however considered to be unsafe as it is very prone to bacterial and pathogenic contamination (Knappett et al. 2011) and commonly also contains high arsenic (Ayers et al. 2017). The pond water is sometimes filtered through a pond sand filter (PSF) with a typical length of $2.7 \mathrm{~m}$ (Yokota et al. 2001), but this filtering has been found to reduce faecal coliforms and $E$. coli by only 75\% (Islam et al. 2011). Users of pond water generally do not perceive their drinking water option very favourably (Naus et al. 2020). Consumption of pond water was considered to bring a large risk of health problems, so when pond water is used as a source for drinking water, the necessity for MAR is deemed to be high.

Groundwater is considered to constitute a safe drinking water option throughout the year when the quality is within the Bangladesh drinking water standards $(\mathrm{EC}<2 \mathrm{mS} / \mathrm{cm}$, As $<0.05 \mathrm{mg} / \mathrm{L}$; Ayers et al. 2016).

Based on the foregoing, as part of this study, rainwater and pond water were considered unreliable and/or unsafe as drinking water sources, and three social necessity classes for MAR were distinguished based on groundwater quality:

1 High necessity, with short-term health problems for MAR when groundwater is saline $(E C>5 \mathrm{mS} / \mathrm{cm})$. Saline groundwater is not palatable and people are expected to likely resort to consumption of pond water, which is highly undesirable.

2 High necessity, with long-term health problems for MAR when shallow groundwater is brackish $(2<\mathrm{EC}<5 \mathrm{mS} /$ $\mathrm{cm}$ ) or is fresh but contains arsenic (As $>0.05 \mathrm{mg} / \mathrm{L}$ ). The long-term effects of brackish and arsenic-rich water (Flanagan et al. 2012; Khan et al. 2014) were considered to carry less of an immediate health risk than switching to pond water, as drinking pond water will likely result in more immediate health problems such as diarrhoea (Islam et al. 2011; Knappett et al. 2011). Nevertheless, these health problems are severe and cannot be treated, so one still considers the necessity to be high.

3 Low necessity for MAR when either shallow or deep groundwater is of good quality with respect to salinity and arsenic according to the Bangladesh drinking water standards. Deep tube wells are predominately placed on a communal level, so they were assumed to meet the drinking water standards.

To map the necessity for MAR in southwestern Bangladesh, the aforementioned criteria for the three necessity classes were applied to the Kriging maps of the groundwater quality, using a GIS overlay to obtain the three social necessity classes for MAR in southwestern Bangladesh. As described in section 'Regional characterisation of groundwater quality', both the EC and arsenic were used for the shallow to intermediate-deep $(0-100 \mathrm{~m})$ groundwater quality, but for the deep $(>100 \mathrm{~m})$ groundwater quality only the EC was considered.

\section{Assessment of the technical suitability}

\section{Constraint mapping}

As a first step in assessing the technical suitability, constraints in the region that rule out the placement and operation of MAR systems were filtered out. This was done using Boolean logic, similar to the approaches by Kallali et al. (2007) and Rahman et al. (2012). The prerequisites are summarised in Table 1. For placement, MAR requires suitable land where infiltration and abstraction wells can be installed and operated continuously (Brown et al. 2005; Ghayoumian et al. 2007). Therefore, the protected Sundarbans mangrove area and the often-inundated aquaculture ponds and tidal river floodplains were filtered out, using a landcover map constructed from supervised classification of Landsat imagery (Naus et al. 2019b).

For operation, MAR requires a sandy aquifer where water can be injected and stored, with the storage capacity, the infiltration capacity and the transmissivity of the aquifer primarily controlling the potential capacity of MAR systems (Ghayoumian et al. 2007; Brown et al. 2005; Chowdhury et al. 2009). The target aquifer was stipulated to have to be present within manual drilling range of up to $60 \mathrm{~m}$ deep, to keep the costs of installation acceptable (Acacia Water 2014a). 
Table 1 Criteria and associated data used for the constraint mapping

\begin{tabular}{llc}
\hline Constraint criteria & Data & Corresponding value \\
\hline Study area & Administrative boundaries & $\begin{array}{l}\text { Satkhira, Khulna, Bagerhat districts: } 1 . \\
\text { Other districts: } 0\end{array}$ \\
& Supervised classification of cloudless imagery & Treed village, one season rice, multiple \\
Inundation likely or & season rice: 1.
\end{tabular}

For the geological constraints, 875 borehole descriptions from the DPHE, BWDB, the UNICEF MAR project, Naus et al. (2019a, b) and Ayers et al. (2016) were collected. Many of the borehole descriptions were collected by drilling using the 'sludger' or 'hand-flapper' method (Horneman et al. 2004) and therefore lack details on storage capacity, infiltration capacity or aquifer transmissivity. To determine whether a sufficiently thick aquifer is present, any material described as sand was assumed to be suitable for the MAR systems, but

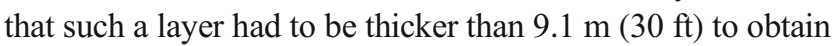
sufficient storage, corresponding to the thickness used as a requirement for the pilot MAR systems (Acacia Water 2014a). The thickness of the aquifer was determined within the first $60 \mathrm{~m}$ for each borehole log, subsequently followed by spatial interpolation using Kriging, for which the same configuration as for the water quality data was used.

\section{Technical performance}

The performance of an MAR system that uses injection and abstraction wells is commonly assessed using the recovery efficiency (RE), defined as the percentage of infiltrated water that can be recovered while maintaining sufficient water quality (Bakker 2010; Maliva et al. 2006; Ward et al. 2009). The $\mathrm{RE}$ can be limited when the quality of the stored water is deteriorated by ambient water, which can occur due to lateral flow, diffusive/dispersive mixing and density-driven flow (Bakker 2010; Lowry and Anderson 2006; Maliva et al. 2006; Ward et al. 2009; Zuurbier et al. 2013).

Lateral flow is caused by the natural hydraulic gradient and leads to the infiltrated freshwater flowing away from the abstraction well. In southwestern Bangladesh, lateral flow was anticipated to be negligible at this time scale (Worland et al. 2015), as the hydraulic gradient in the region was expected to be low because elevation differences are small, and the infiltration rates are low due to the very thick confining clay layer (Naus et al. 2019a; Ayers et al. 2016). Diffusive/dispersive mixing occurs whenever there is a concentration gradient and due to aquifer anisotropy and heterogeneity during lateral flow, density-driven flow and enhanced flow from the injection wells towards the abstraction wells (Ward et al. 2009). In practice, it is difficult to predict diffusive/ dispersive mixing (Ward et al. 2009), especially in southwestern Bangladesh, where data on the anisotropy or heterogeneity of the lithology are sparse. Density-driven flow is caused by density differences between the injected water and the native groundwater. The more saline the surrounding groundwater, the larger the difference in density is, and the larger the buoyant force is from the saline water on the freshwater. The interface between fresh and saline water will consequently be located higher in the aquifer, closer to the filter, making it more likely that upconing of native, saline groundwater will reach the bottom of the abstraction well. Additionally, a larger buoyant force causes injected freshwater to be pushed to the top of the aquifer and consequently to flow away laterally from the abstraction well (Bakker 2010; Ward et al. 2009).

Whenever native groundwater ends up in the well by any of the aforementioned processes or any unforeseen processes, the quality of the abstracted water will decrease, as the primary reason for installing an MAR system in southwestern Bangladesh is that the native groundwater present is not suitable for drinking. Groundwater salinity and arsenic concentration are the two dominant concerns and the vulnerability of an MAR system has been assessed using the groundwater salinity and arsenic database.

The expected technical performance of MAR was assessed by estimating the expected effect of density-driven flow and by estimating the vulnerability to any of the mixing processes. These two variables were combined into one technical suitability index.

The spatial varying magnitude of density-driven flow on the performance of MAR systems was estimated using the method of Bakker (2010). Bakker (2010) describes that the effect of density-driven flow on the RE for an MAR system, typically composed of one joint injection and abstraction well, depends on the duration of the injection period relative to the duration of the storage and abstraction period, and on a dimensionless parameter $\mathrm{D}$ which governs the flow in the MAR system. There are some important differences between the MAR systems for which the D value was developed and the 
MAR systems in southwestern Bangladesh in terms of their design and operation. Firstly, a single well that penetrates the entire aquifer is used for injection and abstraction in the MAR systems of Bakker (2010), whereas the MAR systems in Bangladesh typically have 4-6 infiltration wells with a screen length of $9.1 \mathrm{~m}(30 \mathrm{ft})$ situated around one separate abstraction well with $3 \mathrm{~m}$ (10 ft) screen length of which the lower ends are placed approximately $3 \mathrm{~m}(10 \mathrm{ft})$ higher in the aquifer (Acacia Water 2014a). Secondly, the MAR systems in Bangladesh do not have clearly demarcated injection and abstraction periods. Their continuous injection and abstraction could lead to some of the water having a relatively short storage time, although on average there is a higher injection rate in the wet season and there is a higher abstraction rate in the water-stressed dry season, resulting in net storage from the wet season into the dry season. Despite these differences, the ' $\mathrm{D}$ value' developed by Bakker (2010), as previously used for MAR site selection by Zuurbier et al. (2013), was used as a best estimate of the spatially varying magnitude of density-driven flow on the performance of MAR systems throughout the region:

$D=\frac{Q}{k \alpha H^{2}}$

with $D$ being the $\mathrm{D}$ value, $Q$ being the infiltration and abstraction rate during the days that infiltration or abstraction occurs $\left(\mathrm{m}^{3} /\right.$ day $), k$ being the hydraulic conductivity, $H$ being the thickness of the aquifer and $\alpha$ being the density difference ratio, calculated by:

$\alpha=\frac{\left(\rho_{\mathrm{s}}-\rho_{\mathrm{f}}\right)}{\rho_{\mathrm{f}}}$

with $\rho_{\mathrm{s}}$ being the density of the native saline groundwater and $\rho_{\mathrm{f}}$ being the density of the injected freshwater. The higher the $\mathrm{D}$ value is, the higher the RE. The density of the native groundwater varies spatially and was calculated based on the electrical conductivity of the shallow groundwater $(<60 \mathrm{~m})$, using the 1980 UNESCO state equation typically used for ocean water (for the full documentation, see Fofonoff and Millard 1983). Post (2012) showed these equations to be useable for calculating the density of coastal groundwater. Exact information on the hydraulic conductivity $(k)$ was not available throughout the region, so the value of $k$ was based on the median value of $10.9 \mathrm{~m} /$ day $(\sigma: 5.68)$ obtained from 10 pumping tests performed by Acacia Water (2014b). The other parameters, $H$ and $Q$, are based on the design and capacity of the pilot MAR. $H$ was put at $9.1 \mathrm{~m}(30 \mathrm{ft})$, similar to the length of the filter of the injection wells used in the pilot MAR systems (Acacia Water 2014a), and similar to the minimum required thickness of the aquifer, although the total thickness of the aquifer can be different than $H$. $Q$ was given a value of 5 $\mathrm{m}^{3} /$ day, which is slightly less than the median injection capacity $\left(5.9 \mathrm{~m}^{3} / 8 \mathrm{~h}\right)$ of the pilot MAR systems but higher than the median of the averaged actual infiltration rates per day $\left(3.1 \mathrm{~m}^{3} /\right.$ day; Acacia Water $\left.2014 \mathrm{~b}\right)$.

To interpret an associated RE from the D value, the design, injection, storage, and recovery periods, and the amount of cycles are important (Bakker 2010). Bakker formulated how to translate $D$ into RE for his typical design in which the injection period is of similar duration to the recovery period. Zuurbier et al. (2013), who also applied Bakker's method to assess MAR suitability, used a D value of 14.3 as criterion for well-functioning MAR systems with injection, storage and recovery periods of equal durations, related to an RE of $60 \%$ after five cycles. Due to the aforementioned differences in design and operation between the pilot MAR systems and the MAR systems of Bakker (2010) and Zuurbier et al. (2013), the same criterion could not be used. The Bangladesh MAR systems are likely to be less susceptible to density-driven flow than the MAR systems of Bakker (2010) and Zuurbier et al. (2013) because more upconing is needed for the native groundwater to reach the bottom of the separately installed abstraction well with a screen at shallower depth than the screens for the injection wells (Maliva et al. 2006; Zuurbier et al. 2014). Additionally, the simultaneous injection and abstraction in the MAR systems is likely to result in much shorter average storage times than in the MAR systems of Zuurbier et al. (2013), which will result in less time for density-driven flow and an associated higher RE for similar $D$ values.

In view of the foregoing, the design and operation differences were expected to likely lead to a higher RE for similar D values. As a best guess, a D value of 5 was chosen as the approximate criterion for well-functioning MAR systems, corresponding with an approximate EC of $3.1 \mathrm{mS} / \mathrm{cm}$. In areas with a lower D value, density-driven flow is interpreted to noticeably reduce the efficiency of the MAR system. The D value instead of an associated $\mathrm{RE}$ value was decided to be reported, as the associated RE value is subject to MAR design choices and interpretation whereas the $\mathrm{D}$ value is closer to a subsurface property. For guidance, a $\mathrm{D}$ value above 5 is expected to likely lead to an RE higher than $60 \%$ and a $\mathrm{D}$ value below 1 is expected to likely lead to an RE of approximately $25 \%$ in the unmodified pilot MAR design.

The vulnerability to water quality deterioration due to mixing was expressed by calculating the fraction of native water that would result in the water quality being below the water quality standards of the Bangladesh government (Ayers et al. 2016). The maximum fraction of native water $\left(f_{\mathrm{i}}\right)$ in the abstracted water before a certain compound $i$ deteriorates the abstracted water was calculated as follows:

$f_{\mathrm{i}}=\frac{i_{\mathrm{c}}-i_{\mathrm{i}}}{i_{\mathrm{n}}-i_{\mathrm{i}}}$ 
with $i_{\mathrm{c}}$ being the concentration criterion according the drinking-water-quality standards, $i_{\mathrm{i}}$ being the concentration of the compound in the injected water, and $i_{\mathrm{n}}$ being the concentration of the compound in the native groundwater. The smaller the fraction, the less water is needed to deteriorate the water quality of the extracted water and the higher the vulnerability to any of the aforementioned processes. Vulnerability to deterioration was calculated for EC and arsenic, with the lowest value for these two determining when the water quality would be considered as deteriorated. For the quality of the native groundwater, data points for groundwater down to approximately $60 \mathrm{~m}$ deep from the water quality database were used, as described earlier.

To summarise the technical suitability of the region for MAR, the expected density-driven flow in the form of the calculated $\mathrm{D}$ value and the vulnerability to the mixing processes were combined in one technical suitability index. For this, a weighted linear combination (WLC) was used, similarly to Saraf and Choudhury (1998) and Rahman et al. (2012):

WLC, $S\left(x_{\mathrm{i}}\right)=\sum w_{\mathrm{i}} \cdot s_{\mathrm{i}}\left(x_{\mathrm{i}}\right)$

in which $w_{\mathrm{i}}$ is the weight of each criterion, the sum of the weights is 1 , and $s_{\mathrm{i}}\left(x_{\mathrm{i}}\right)$ are the standardised criteria. Equal weights were used for the expected density-driven flow and for the permitted fraction of native groundwater, i.e., $w_{\mathrm{i}}=0.5$.

The $\mathrm{D}$ value and the permitted fraction of native groundwater were standardised so that they both had the same scale of 0 (no suitability) to 1 (high suitability). For standardisation of the $\mathrm{D}$ value, areas with a $\mathrm{D}$ value below 5 were interpreted as likely to be influenced by density-driven flow, corresponding to a standardised value of 1 , which decreases linearly to 0 when the $\mathrm{D}$ value is 0 . For the permitted mixing fraction, the standardisation was based on the scenarios described by Ward et al. (2009), which regularly have mixing of up to $20 \%$ native water. The vulnerability was standardised linearly from 0 at $0 \%$ native water needed to deteriorate the water quality, to a vulnerability of 1 when more than $30 \%$ native water is needed to deteriorate the water quality. The resulting technical suitability index is not absolute but relative. Areas with a high index are more likely to have a technical well-functioning MAR system, but areas with a low index are not guaranteed to have nonfunctional MAR systems.

\section{Results}

\section{Social necessity for MAR}

Figure 3 shows the spatial distribution of the necessity for MAR systems as inferred from groundwater quality. Note that the necessity applies particularly to the dry season, as rainwater is abundant during the monsoon. Larger areas in the middle/north and in the west, and smaller areas in the southwest and northeast, have groundwater of adequate quality available, indicating MAR systems are not necessary. Note that these areas mostly have safe deep groundwater available for use. Shallow groundwater is suitable for use as drinking water in only a few locations in the middle/north. The rest of the area has groundwater of inadequate quality because of its arsenic content and/or salinity. Although the groundwater quality in eastern Sathkira and in northern Bagerhat is mostly limited by arsenic, it is nonetheless probably consumed, stressing the high necessity for safer water sources, albeit at a longer time scale. In the southern part of the region, salinity renders the groundwater unusable. Here, consumption of bacteriologically unsafe pond water was presumed to occur frequently and, therefore, there is great need for better water options at a short time scale.

\section{Technical suitability}

\section{Constraint mapping}

The protected Sundarbans and the frequently inundated areas (containing aquaculture and (tidal) river floodplains) largely limit the areas where MAR systems can be installed (Fig. 4). The Sundarbans in the south do not contain any permanent settlements, so local scale MAR systems would not be needed. The aquaculture is located in the west and southeast of the region. In the narrow bands with small villages on dry land between the inundated areas with aquaculture, MAR can be installed, although the land available will be limited and care should be taken to prevent lateral inflow of infiltrated saline aquaculture water.

The Kriging results of 875 borehole logs indicate that throughout the region, aquifers thicker than the formulated

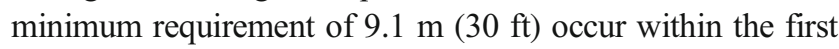
$60 \mathrm{~m}$ (Acacia Water 2014a), so aquifer thickness is no significant constraint for MAR implementation (see Appendix; Fig. 10). Nonetheless, 48 borehole logs (approximately 5\%) indicate that local aquifer thickness may be less than $9.1 \mathrm{~m}$. Since variation in lithology is large, this reveals that aquifer thickness cannot be accurately predicted on a regional scale, indicating the need for a test drilling when selecting sites for MAR.

\section{Density-driven flow}

The expected influence of density-driven flow, expressed in D values, varies with the groundwater salinity patterns in the region (compare Fig. 5 with the Appendix; Fig. 11). In the northwest and northeast, the $\mathrm{D}$ values exceed 10 , indicating that density-driven flow is not expected to be an issue for the functioning of MAR systems. In large areas of the region, mainly the middle and south, the $\mathrm{D}$ values are below 5 , 
Fig. 3 Spatial distribution of necessity for MAR as a function of observed groundwater quality, using the Bangladesh drinking water standards for salinity (EC) and arsenic (As) as indicators

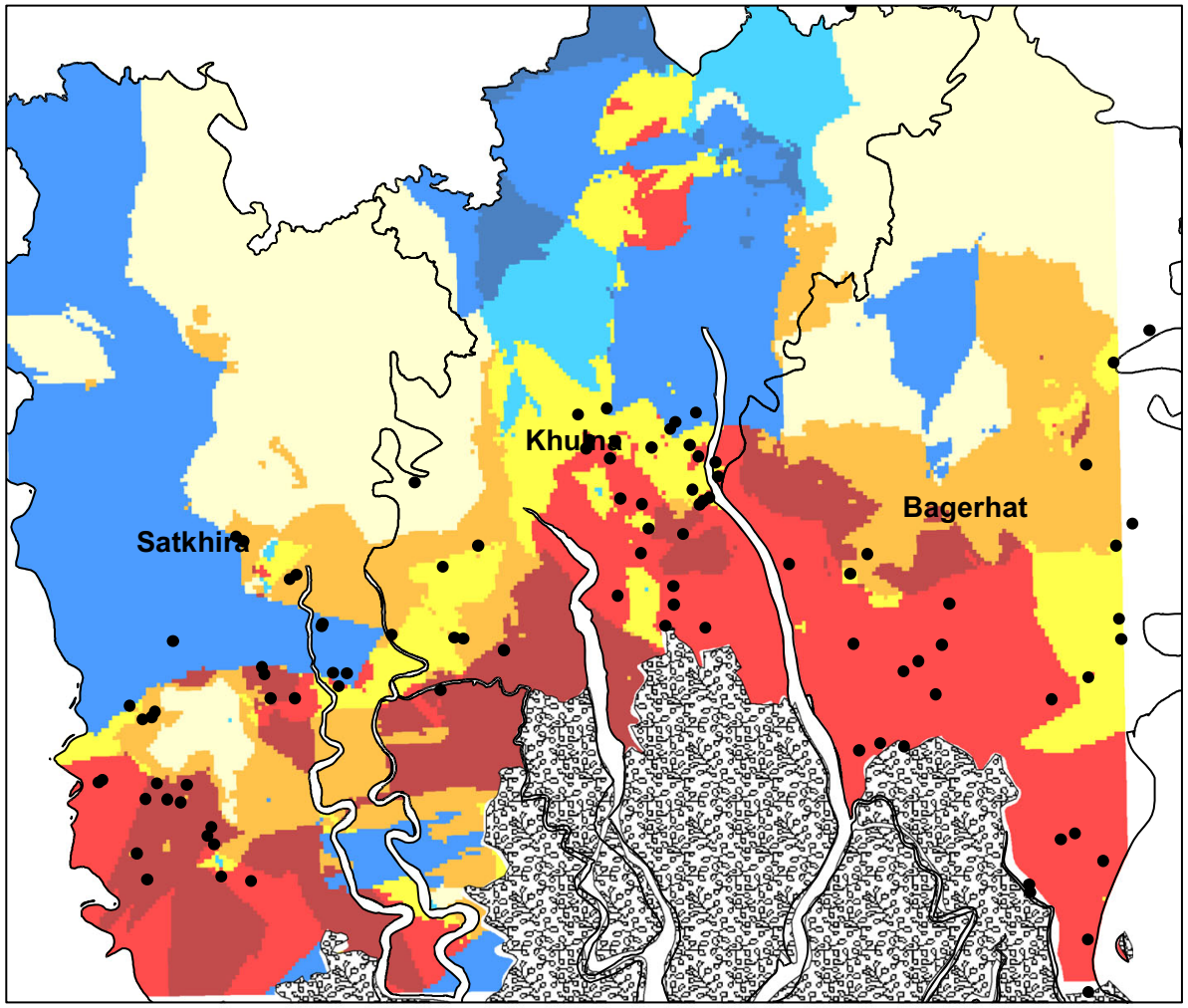

Legend

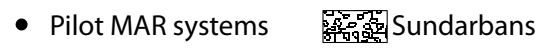

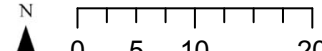

20 Kilometres

\begin{tabular}{|l|l|l|l|l|}
\hline \multirow{2}{*}{ Necessity for MAR } & \multicolumn{2}{|l|}{ Shallow and intermediate deep } & \multicolumn{2}{|c|}{ Deep } \\
\cline { 2 - 5 } & $\mathrm{EC}(\mathrm{mS} / \mathrm{cm})$ & As $(\mu \mathrm{g} / \mathrm{l})$ & $\mathrm{EC}(\mathrm{mS} / \mathrm{cm})$ & As $(\mu \mathrm{g} /$; assumed $)$ \\
\hline \multirow{2}{*}{ Low } & $<2$ & $<50$ & $<2$ & $<50$ \\
\hline \hline & $>2$ & $>50$ & $<2$ & $<50$ \\
\hline
\end{tabular}

\begin{tabular}{|l|l|l|l|l|}
\hline High, long term & $<2$ & $>50$ & $>2$ & $<50$ \\
\hline High, long term & $>2,<5$ & $<50$ & $>2$ & $<50$ \\
\hline High, long term & $>2,<5$ & $>50$ & $>2$ & $<50$ \\
\hline
\end{tabular}

\begin{tabular}{|l|l|l|l|l|}
\hline High, short term & $>5$ & $<50$ & $>2$ & $<50$ \\
\hline High, short term & $>5$ & $>50$ & $>2$ & $<50$ \\
\hline
\end{tabular}

indicating that the effect of density-driven flow is expected to reduce $\mathrm{RE}$, potentially affecting the feasibility of MAR. In the southwest and southeast of the region, the $\mathrm{D}$ values are lower than 1 , which is interpreted to lead to an RE below approximately $25 \%$. This indicates significant influences of densitydriven flow, compromising the practical application of the technology.

Since the D values were calculated using $Q$ and $H$ from the pilot MAR sites, they are generally relevant for predicting the effect of density-driven flow on MAR systems having the same design and infiltration regime as the pilot systems. The relatively low infiltration and abstraction rates $(Q=5)$ of the pilot MAR sites cause density-driven flow to be already relevant $(\mathrm{D}$ values $<5$ ) in areas with a relatively low salinity $(\mathrm{EC}>3.1 \mathrm{mS} / \mathrm{cm})$. Indeed, the $\mathrm{D}$ value is lower than 5 at almost all locations where brackish groundwater is present.
This indicates that either the MAR users should be satisfied with lower REs, or that improvements in the operational and design aspects should be considered.

\section{Vulnerability map}

Figure 6 shows the percentage at which mixing of infiltrated freshwater with native groundwater causes abstracted MAR water to fail to comply with the drinking water standards for salinity or arsenic. In this assessment, the data on shallow (0$60 \mathrm{~m}$ ) groundwater quality were used (as shown in the Appendix; Fig. 11) and potential hydrogeochemical processes affecting arsenic were ignored. Mixing is caused by dispersion and imperfect design: for example, when the abstraction well starts to tap native groundwater while there is still artificially infiltrated water in the system. Several patterns are clearly 
Fig. 4 Areas potentially suitable for MAR, based on excluding areas with inundation likelihood and protected area status

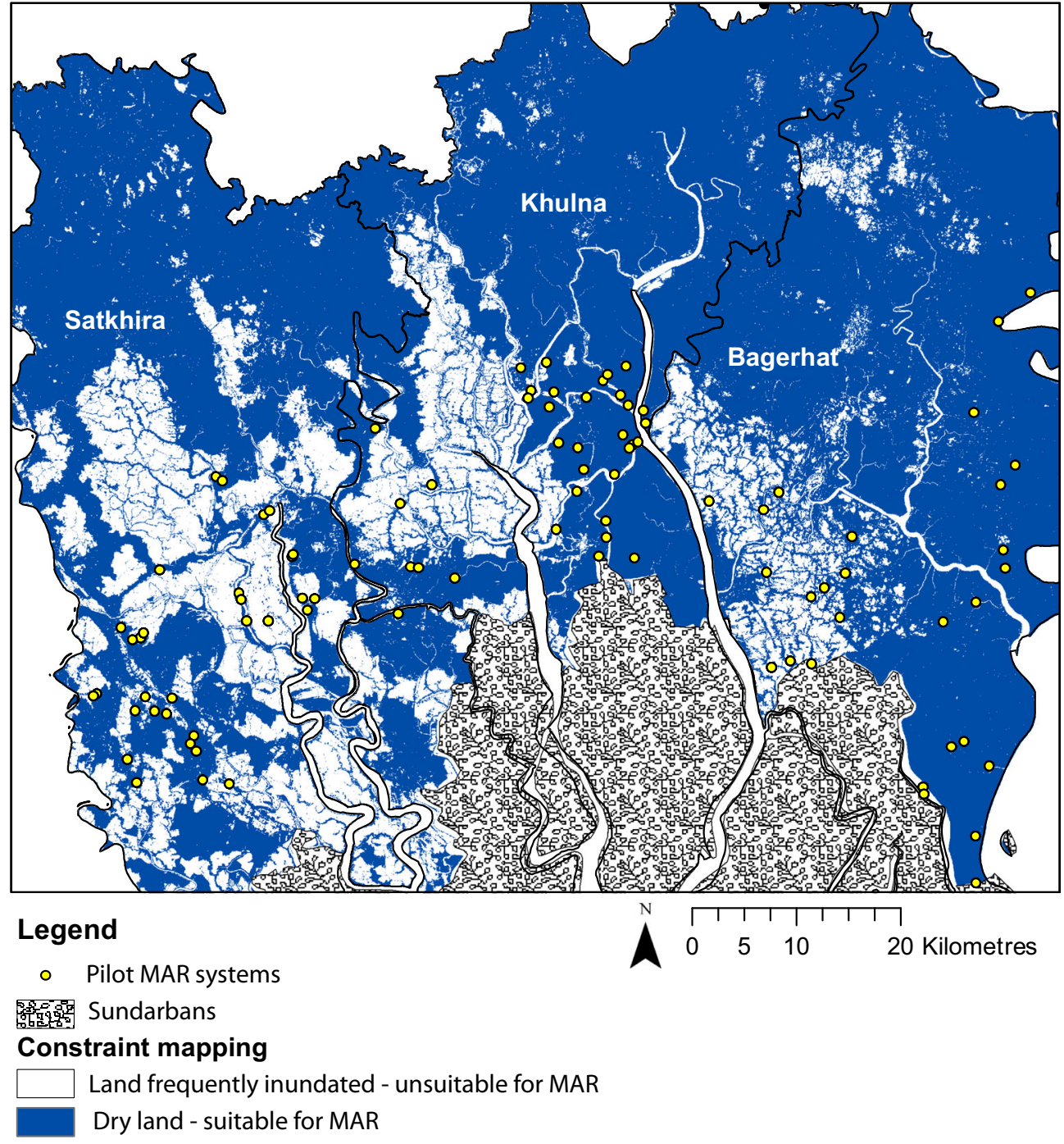

visible: areas in the northwest and northeast are more sensitive to arsenic than to salinity, while areas in the southwest and southeast and in the middle of the region are more sensitive to salinity than to arsenic. The lower the maximum fraction of native groundwater (Eq. 3 ), the higher the sensitivity to mixing, as mixing with less native groundwater would already exceed a drinking water standard (for salinity or arsenic) of the recovered water. This means that when any unforeseen mixing occurs, or when the mixing zone reaches the abstraction well filter, abstraction has to be stopped sooner, which will reduce the average $\mathrm{RE}$. The susceptibility to mixing is the largest in the saline southwest and southeast, where mixing with less than $15 \%$ native groundwater will already cause the salinity standard for drinking water to be exceeded. In the northwest and the northeast, the mixing risk is still quite large even though salinity is low, because arsenic concentrations are high: 15-30\% native groundwater will already cause the arsenic standard to be exceeded.

\section{Technical suitability index}

Figure 7 presents a map of the technical suitability index, for which the constraint mapping, the density-driven flow effect assessment and the vulnerability to mixing assessment were combined. There are clear differences in the technical suitability for MAR systems over the study region. The spatial patterns are largely dictated by the groundwater salinity patterns, due to the two-fold influence of groundwater salinity on the technical suitability: it impacts both the likelihood of densitydriven flow and the negative effect of mixing. This results in the overall pattern showing a decrease in technical suitability index towards the south, with the southeast having the lowest technical suitability index. However, note that areas having high groundwater arsenic concentrations such as the northeast also have a technical suitability index below 1 , due to the risk for mixing with native arsenic-contaminated native groundwater. 
Fig. 5 Relative influence of density-driven flow on the efficiency of MAR systems for recovering infiltrated freshwater in brackish aquifers based on the $\mathrm{D}$ value, which is a dimensionless indicator for the impact of density-driven flow (Bakker 2010). The lower the calculated $D$ value, the higher the relative influence of density-driven flow

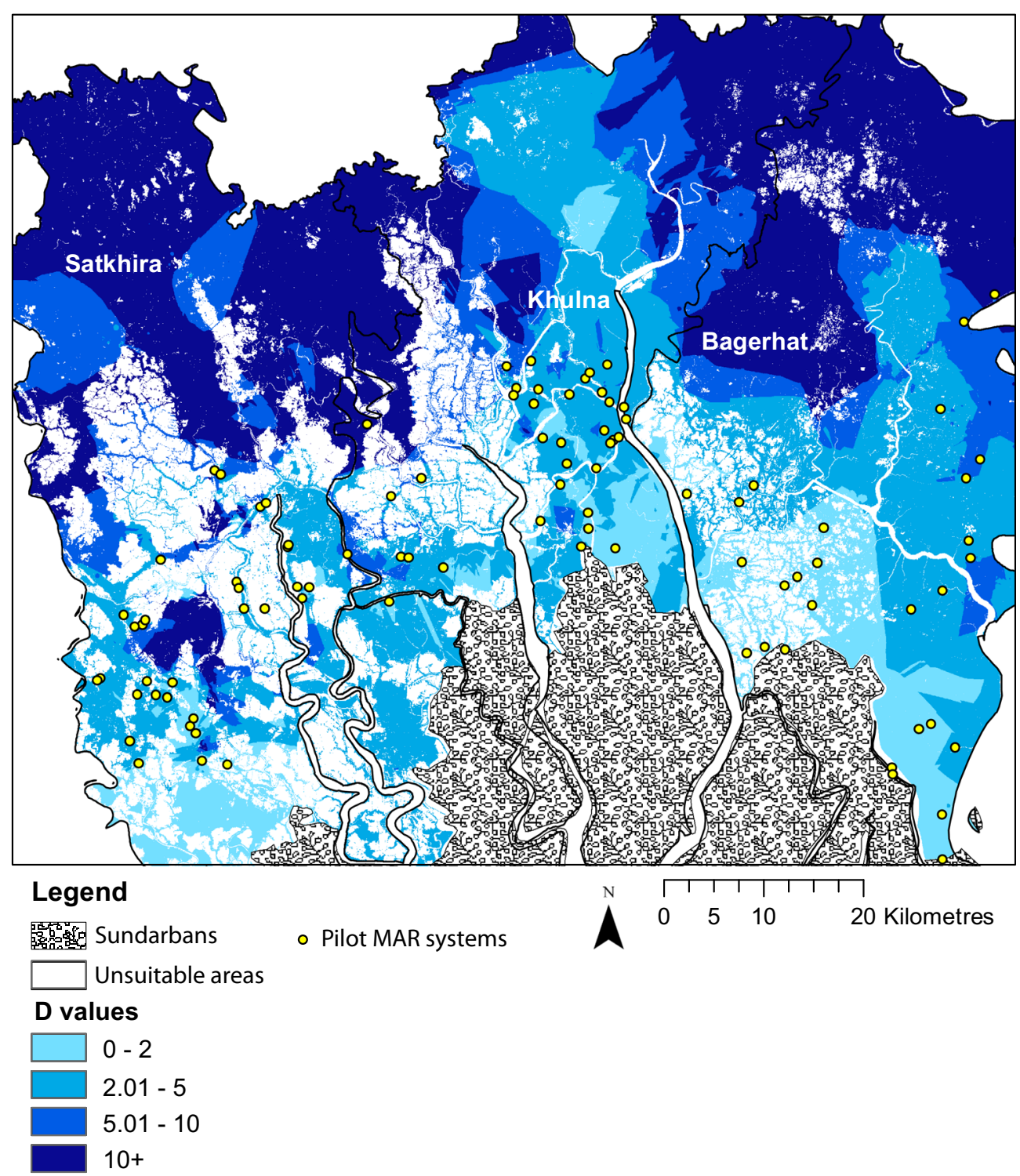

\section{MAR potential combining social necessity and technical suitability}

The outcome of combining the necessity assessment (Fig. 3) and the technical suitability assessment (Fig. 7), is presented in Fig. 8. This combination determines the potential for MAR in the region. This potential is highest in areas where necessity and technical suitability are both high. The combined map shows that these high potential areas are mostly located in the northern part of the region, where the technical suitability index is high, and the high necessity is caused by arsenic-rich groundwater.

There are few areas with good potential for MAR to overcome the short-term health effects of drinking surface water, for which MAR was originally designed. There appears to be a mismatch between the technical suitability and the short- term high necessity for MAR. The technical suitability index is often below 0.75 or even below 0.5 in the areas with a high short-term necessity for MAR. These areas are mostly in the south of the region, near the Sundarbans.

\section{Discussion}

\section{Evaluation of the regional MAR potential}

The potential for MAR throughout the region is controlled by both the necessity and technical suitability for MAR. The results of the necessity assessment (Fig. 3) provide the first clear and comprehensive spatial overview of drinking-waterquality problems in the region, based on the most exhaustive groundwater quality database for the region to date. This 
Fig. 6 Vulnerability map of MAR water to mixing with native groundwater either due to arsenic (green) or salinity (blue). The percentage of native groundwater mixing is shown that would cause MAR water quality to exceed the Bangladesh drinking water standards. The lower the percentage, the more vulnerable the MAR system is (the lighter the colours)

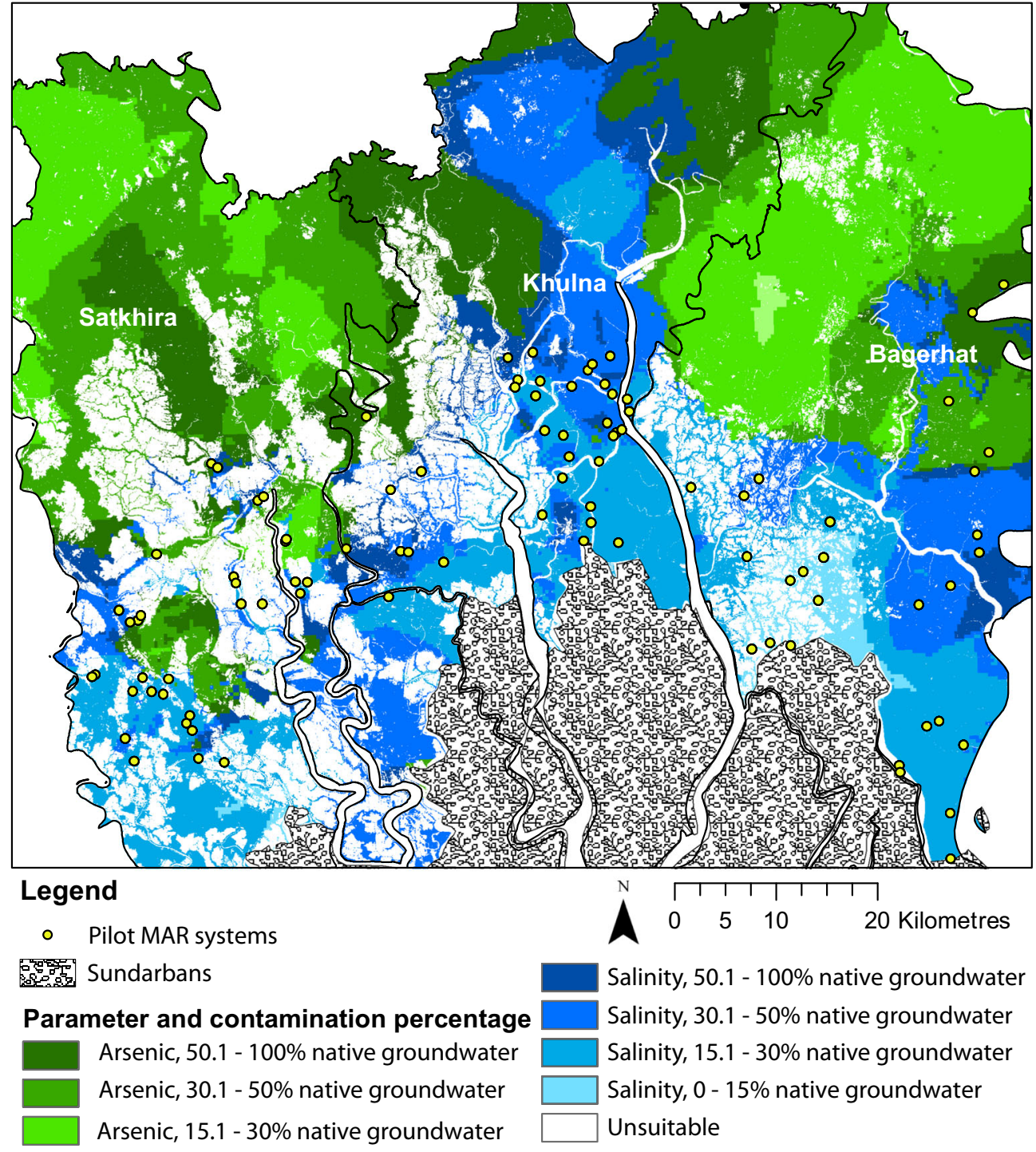

Arsenic, 0 - 15\% native groundwater reveals the areas where MAR may be applied to establish safe drinking water supply and could be used to develop a regional water-resource-management strategy. The technical suitability map provides valuable insights into the likelihood that MAR will function well and efficiently from a hydrogeological point of view.

In areas without a necessity for MAR, installing MAR systems may not be effective to solve current drinking water problems as the local people are not expected to be sufficiently motivated to pay for or adopt the MAR systems. Therefore, the potential for MAR in these parts was interpreted to be low, even though MAR systems would be unlikely to face technical issues. However, MAR could still become relevant in the future as a sustainable water option, especially when abstraction of groundwater becomes unsustainable, as has been shown in other parts of
Bangladesh (Shahid and Hazarika 2010; Hoque et al. 2007) and to enlarge the water availability in dry periods.

In the areas with a high necessity with long-term health problems and high technical suitability, MAR systems have potential to solve the current drinking water problems related to consumption of groundwater with unacceptable levels of arsenic or salinity. In these areas, technical complications are not expected, but the acceptance and adoption of communityrun MAR systems could be problematic, as it has been found that people are attached to using their shallow tube wells as source of drinking water (Naus et al. 2020), even though arsenic concentration is high.

In areas with both a high necessity with short-term health problems and a low technical suitability, it is likely that community-run MAR systems will be accepted and adopted, 
Fig. 7 Technical suitability index for MAR throughout the study region. The lower the index value, the lower the expected technical performance of the MAR systems given the local hydrogeological conditions, with a higher chance of insufficient MAR water quality

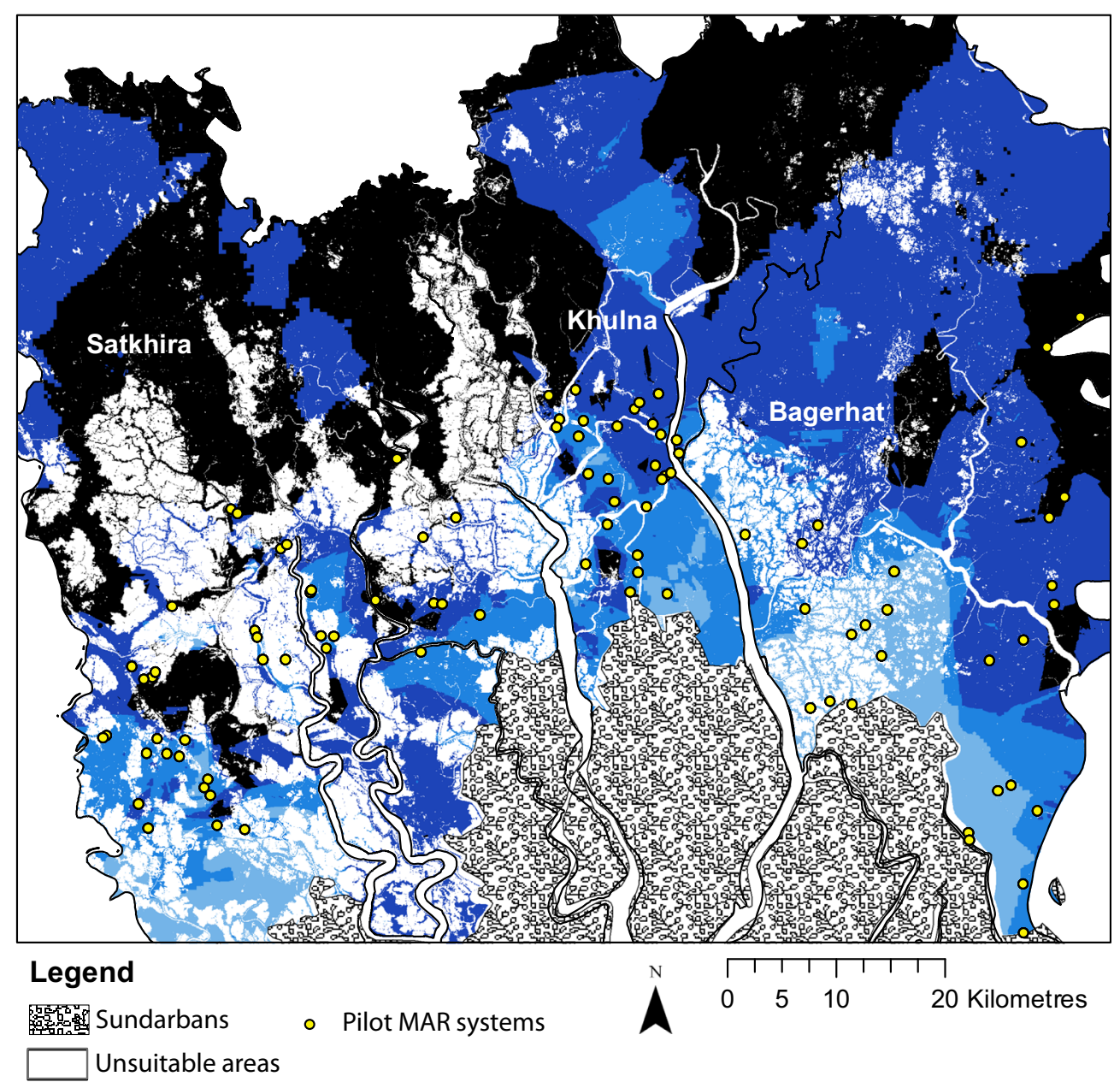

Technical suitability index

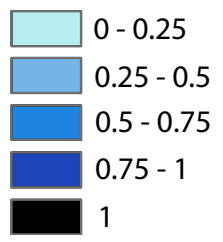

as it has been found that people are less attached to drinking pond water (Naus et al. 2020). However, MAR systems are unlikely to function optimally because of high groundwater salinity and associated mixing with native saline groundwater. Nevertheless, MAR systems could still provide a valuable bacterially safe drinking water source, especially when systems with a larger capacity are constructed to increase the RE (see section 'Enhancing MAR capacity to improve performance'). It is therefore expected that there is potential for MAR in these areas, but to achieve and maintain efficient systems in this part of the region, it is recommendable to carefully, a priori, assess technical MAR functioning together with a targeted extracted water-quality-monitoring strategy. Below recommendations for better monitoring and performance of MAR systems are discussed.

\section{Recommendations for the monitoring of MAR systems}

While the MAR systems are operating, the chemical water quality of the abstracted water should be monitored so abstraction can be stopped when the abstracted water is no longer safe for use. The monitoring of the pilot MAR sites stopped after a few years and should be restarted. It should be noted that MAR water can also be of insufficient quality if pathogens remain in the water: Sultana et al. (2015) and Kabir et al. (2016) showed that $E$. coli was not fully removed in some of the pilot MAR sites, so monitoring of microbial water quality is also required.

The vulnerability map (Fig. 6) is useful for developing strategies for monitoring chemical water quality. Firstly, the 
Fig. 8 Potential for MAR based on the combination of the necessity for MAR and the technical suitability index. The higher the necessity and technical suitability index, the higher the potential for MAR
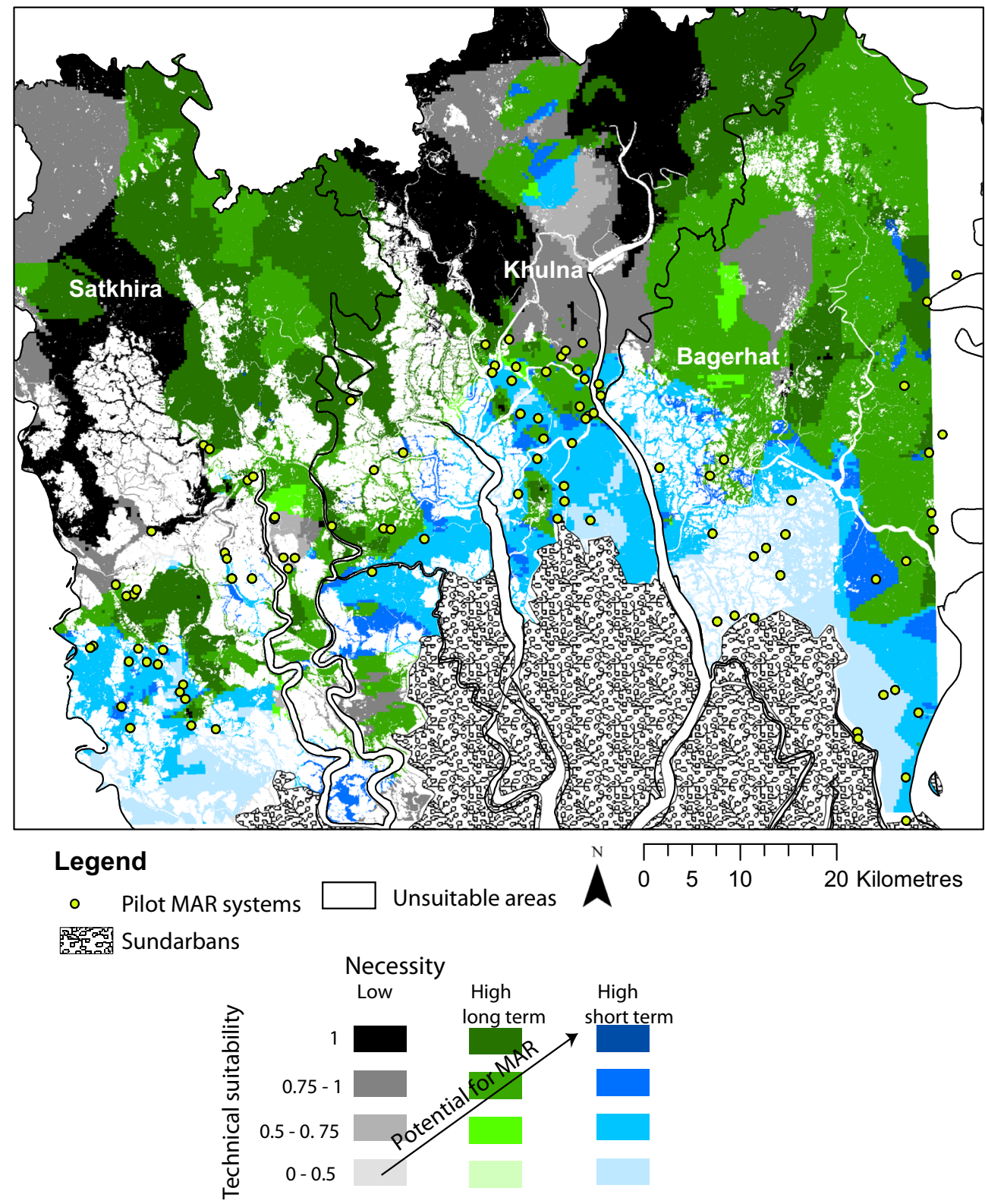

map reveals which water quality parameter (salinity or arsenic) will likely exceed the drinking water standard first, so the map can be used to decide which parameter has monitoring priority during operation of the MAR systems. In the south and middle of the region, salinity monitoring with EC measurements will suffice to detect the abstraction of unsafe water (on the condition that arsenic is not mobilised under sitespecific conditions), while in the northwest and northeast, arsenic monitoring should have priority. Possibly sensor measurements $(\mathrm{EC}, \mathrm{pH})$ are still useful on site-specific basis to identify mixing with native groundwater and thus increased risk for As contamination. It should be noted that during MAR operation geochemical processes may occur with consequences for arsenic concentrations. Arsenic and iron may become immobilised when infiltrated aerobic water causes iron oxides to form (van Halem et al. 2010; Rahman et al. 2015), but the reverse process may occur when organic matter remains in the infiltrated water and becomes oxidised by iron oxides, resulting in arsenic and iron mobilisation (Ravenscroft et al. 2005).

Secondly, the calculated mixing fraction is also a useful parameter to determine the frequency of monitoring: the lower the percentage of native groundwater needed to compromise the quality of the abstracted water, the more frequent the monitoring should be, especially towards the end of the dry season when little freshwater is stored underground. In the areas vulnerable to mixing with native groundwater containing arsenic, it is recommended that monitoring is frequent, since arsenic is not detected by taste, whereas salinity is, and to account for the aforementioned geochemical processes. 


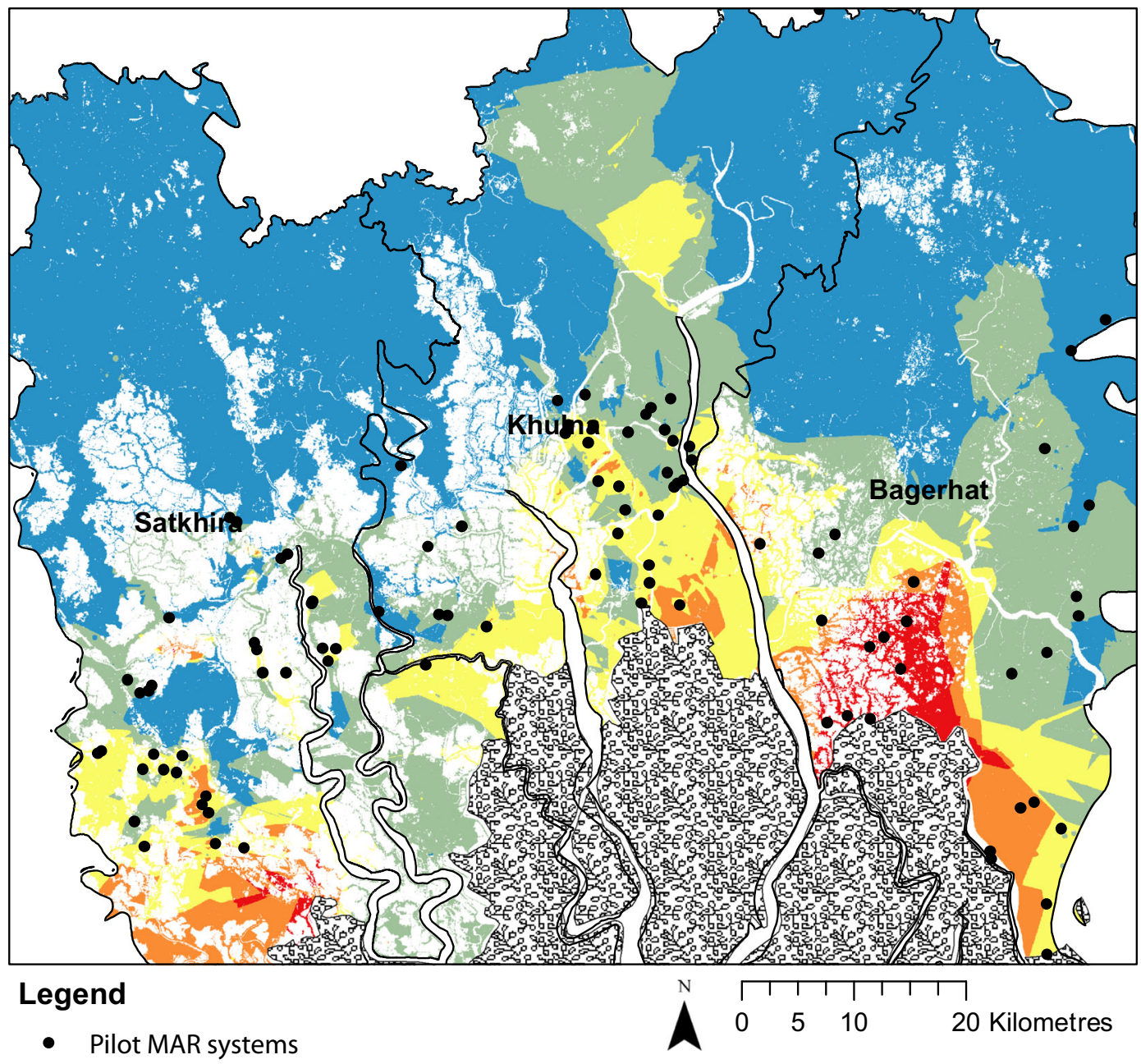

Sundarbans

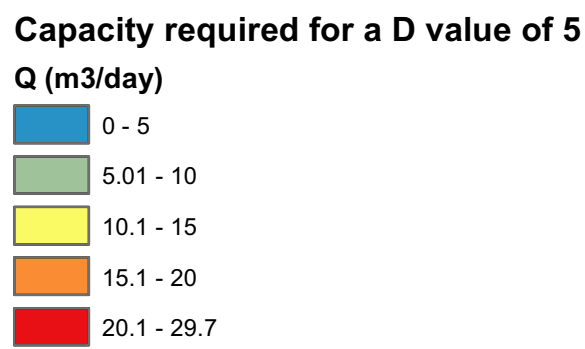

Fig. 9 Required average infiltration (and abstraction rate) per day (capacity MAR system) to achieve a D value of 5, corresponding with a recovery efficiency of approximately $60 \%$

\section{Enhancing MAR capacity to improve performance}

One may note that the $\mathrm{D}$ value follows from both given hydrogeological conditions (hydraulic conductivity, aquifer thickness, density contrast with native groundwater) and the applied infiltration/abstraction rate. $\mathrm{D}$ values are low over much of the region but would increase if the applied infiltration/ abstraction rate is enhanced. Larger infiltration and abstraction rates $(Q)$ are directly related to a higher $\mathrm{D}$ value (Eq. 1). Thus, when more water is infiltrated (and abstracted) and the capacity of MAR systems is increased, the technical performance of the MAR will also be better. Consequently, the relative loss of water due to density-driven flow can be reduced by primarily increasing the infiltration (and the abstraction) rate of the MAR systems. The calculated $\mathrm{D}$ value can be translated into a practical guideline for the approximate MAR capacity required to achieve sufficiently high recovery efficiencies. The $Q$ required to limit the impact of density-driven flow and make MAR technically feasible throughout the region was calculated. To this end, the $\mathrm{D}$ value was fixed in Eq. (1) at 5 (interpreted to correspond to an expected 
Table 2 MAR technical suitability classes compared to the performances of the pilot MAR sites judged by 'Best performance' and 'Performance at end of dry season'

Technical suitability classes Number of pilot MAR sites Best performance ${ }^{\mathrm{a}}$

Performance at end of dry season (20 June 2016) ${ }^{\mathrm{b}}$

\begin{tabular}{|c|c|c|c|c|c|}
\hline & & & & & \\
\hline & & $\begin{array}{l}\text { At least once produced } \\
\text { water of sufficient quality }\end{array}$ & $\begin{array}{l}\text { Never produced water } \\
\text { of sufficient quality }\end{array}$ & $\begin{array}{l}\text { Sufficient quality } \\
\text { on } 20 \text { June } 2016\end{array}$ & $\begin{array}{l}\text { Insufficient quality } \\
\text { on } 20 \text { June } 2016\end{array}$ \\
\hline$<0.5$ & 20 & $15(75 \%)$ & $5(25 \%)$ & $7(35 \%)$ & $13(65 \%)$ \\
\hline $0.5-0.75$ & 33 & $26(79 \%)$ & $7(21 \%)$ & $10(30 \%)$ & $23(70 \%)$ \\
\hline $0.75-1$ & 27 & $22(82 \%)$ & $5(19 \%)$ & $10(37 \%)$ & $17(63 \%)$ \\
\hline 1 & 6 & $5(83 \%)$ & $1(17 \%)$ & $3(50 \%)$ & $3(50 \%)$ \\
\hline Grand total & 86 & $68(79 \%)$ & $18(21 \%)$ & $30(35 \%)$ & $56(65 \%)$ \\
\hline
\end{tabular}

${ }^{\mathrm{a}}$ The best produced water quality

${ }^{\mathrm{b}}$ The produced water quality after prolonged operation (on 20 June 2016, towards the end of dry season)

$\mathrm{RE}$ of $60 \%$ ), and the equation was subsequently solved for $Q$, similar to Zuurbier et al. (2013). The resulting $Q$ values was used as a guideline for the approximate target capacity of the MAR systems required to achieve proper technical functioning (Fig. 9). In most of the region, a $\mathrm{D}$ value of 5 is achieved when the present median infiltration and abstraction rates are doubled from 5 to 10 $\mathrm{m}^{3} /$ day. In the saline south of the region, however, higher infiltration and abstraction rates are required to achieve a $\mathrm{D}$ value of 5: up to a maximum of $30 \mathrm{~m}^{3} /$ day. To assess the feasibility of achieving these capacities, they were compared to the infiltration rate of the current pilot MAR systems. The assessed capacity of the infiltration rate of the current MAR systems varies between 1 and $19.4 \mathrm{~m}^{3} /$ day, with $5.9 \mathrm{~m}^{3} /$ day as median value, based on $8 \mathrm{~h}$ of infiltration (a value of $5.0 \mathrm{~m}^{3} /$ day was used in this study's assessment). This median value is lower than the $Q$ required in a large part of the region, revealing that the current pilot MAR systems will probably not achieve a high RE. It is possible to increase the infiltration rate of the systems by increasing the hours of infiltration per day, by decreasing the resistance for infiltration (the wells are presently filled with gravel), or by installing more or larger sand filtration chambers and infiltration wells. For example, doubling or tripling the infiltration time per day and the number of infiltration wells would result in a 4-9 times increase in infiltration capacity, making the MAR systems feasible in almost the entire region. The relatively thin aquifers expected in the south (Appendix; Fig. 10) may limit the possibility of applying long infiltration wells.

An increase in infiltration capacity may be limited by the amount of source water available. The current MAR systems take most of their water from ponds. Data on the surface sizes of these ponds next to the MAR sites provided by the staff of the UNICEF MAR project revealed that pond size varies greatly: between 575 to $8,261 \mathrm{~m}^{2}$ with a median size of $1,486 \mathrm{~m}^{2}$. If only the net direct rainfall (here taken to be $2,000 \mathrm{~mm} /$ year) to the ponds is assumed to be usable for infiltration (and not also inflow from surrounding areas), the available source water is as little as $1,150 \mathrm{~m}^{3} /$ year for the smallest ponds, and $16,722 \mathrm{~m}^{3} /$ year for the largest ponds, with a median of $2,972 \mathrm{~m}^{3} /$ year, which would allow for a infiltration rate between 6.4 and $92.9 \mathrm{~m}^{3} /$ day during the wet season (180 days), with a median of $16.5 \mathrm{~m}^{3} /$ day. MAR systems with an infiltration rate at the lower end of the estimate would therefore be unsuitable in the southern part of the area, but the low estimates are still higher than the assumed value of 5 $\mathrm{m}^{3} /$ day. This large range underlines the importance of taking the size of the pond (as key rainfall harvesting structure) into consideration during site selection. For MAR sites to have sufficient capacity to function well in the south, it is thus essential to have a large pond or to incorporate additional ways of collecting water, for example, from large roofs.

\section{Reflection on uncertainties}

The results were not intended to provide the definite locations where MAR should be applied but rather to assist in developing a strategy for the implementation of MAR throughout the region. They should, therefore, be seen as providing regional indications for the potential for MAR. In the following, uncertainties in the results arising from the methodology, local hydrogeological variation and locally available alternative drinking water options are discussed which should be taken into consideration when developing regional MAR implementation strategies.

\section{Methodological uncertainty}

The technical suitability and required infiltration rate are only indicative, as the D value was not specifically developed for the design and operational conditions of these specific MAR systems and required interpretation (section 'Technical performance'). The effective storage time of the water in the MAR systems might be much shorter than assumed, which would 
allow for less time for density-driven flow and an associated higher RE for similar D values. Similarly, the interpretation that the smaller susceptibility to density-driven flow due to infiltration and abstraction at different depths leads to a more efficient system may not hold true for these small MAR sites; Barker et al. (2016), who modelled a pilot MAR system (albeit with different assumptions), found that the design is more efficient when both infiltration and abstraction are applied along the entire depth of the aquifer than at present with a much shorter abstraction well (10 versus $30 \mathrm{ft}$; 3.048 versus $9.144 \mathrm{~m})$.

An additional uncertainty is introduced by the value used for the hydraulic conductivity when calculating the $\mathrm{D}$ value, namely the median value of $10.9 \mathrm{~m} /$ day ( $\sigma$ is 5.68) from 10 pumping tests performed by Acacia Water (2014b). The hydraulic conductivity of the aquifer has a direct effect on the assessed effect of density-driven flow: when the hydraulic conductivity is twice as low, the D value is also twice as low. The effect of hydraulic conductivity is clear when the results are compared with those of Barker et al. (2016), who modelled a pilot MAR system using an aquifer hydraulic conductivity of $0.2 \mathrm{~m} /$ day. Their 50 times lower hydraulic conductivity results in $\mathrm{D}$ value that is 50 times higher. Consequently, their model predicted limited influence of density-driven flow, despite the native groundwater being relatively saline.

Another uncertainty is introduced because hydrogeochemical processes were ignored, due to their large complexity. There are uncertainties regarding both the exact chemical substances in the water and the soils, and the redox and $\mathrm{pH}$ states in the water-sediment system. Therefore, it is uncertain which processes would occur and it is uncertain how much impact the processes would have. While this simple mixing process of the vulnerability mapping does provide an important first indication of the risks, subsequent work could aim to take these hydrogeochemical processes into account.

\section{Local hydrogeological variation}

The results reveal the main patterns at a regional scale but there may be deviations at local scale because the local hydrogeological variation is large and may not be fully captured by the datasets, and is also partly smoothed due to Kriging interpolation. Even though the most exhaustive groundwater quality databases available were used, the area is known for its large local hydrogeological variation (Ayers et al. 2016; Naus et al. 2019a, b). As mentioned in the results, the Kriged aquifer thickness predicts the aquifer to be thicker than $9.1 \mathrm{~m}$ throughout the region, despite 48 out of 875 borehole logs indicating a thinner aquifer. Similarly, the hydraulic conductivity of the aquifer is likely to have large local variation, suggesting a local $K$ value should be estimated during local site assessment. For the water quality, it is also likely that some of the local variation is smoothed during Kriging. As a consequence, the necessity and technical suitability for MAR at a local scale may be different than inferred from the regional overview.

In addition, the assumption that the lateral groundwater flow is negligible might not hold true in some local circumstances. At a local scale, it is possible that lateral flow (e.g. caused by pumping nearby) can affect the functioning of the MAR systems. For these reasons, MAR implementation should always be preceded by assessing the local hydrogeological situation at the site of interest.

\section{Local alternative water options}

Another uncertainty concerning the applicability at the local scale involves the assessed drinking water options that determine the necessity for MAR. While the main water options in the region (rainwater, pond water, groundwater) were considered, it should be noted that MAR was found to still experience competition of these main water options: the more main options people have available, the less interested they are in MAR (Hasan et al. 2019). MAR was found to be the least preferred alternative compared to these other options by locals, nongovernmental organizations, and environmental science academics (Peters et al. 2019; Nizame et al. 2020). Most notably, Peters et al. (2019) indicate that MAR scores low for the social criteria, due to misunderstanding concerning ownership and responsibility of maintenance, which indicates the importance of evaluating and tackling these social issues before new MAR systems are implemented. Additionally, this reveals that, whenever the other main options can feasibly provide good quality water, they are likely a better option than MAR; however, as discussed in the methods, there are areas where these options currently cannot provide good quality water year-round.

Aside from the main options, there are some other less used alternative drinking water options, although adequate information on their presence is not available - for example, reverse osmosis (RO) systems have been implemented recently in the region. These systems can remove bacteria, salinity and arsenic from water (Islam et al. 2018; Ning 2002); however, the construction costs, maintenance costs, and energy demand of these RO systems are all high and their robustness over longer time periods is not yet known: RO systems in southwestern Bangladesh are reported to not always succeed in lowering the salinity of the water (Islam et al. 2018). Nevertheless, the presence of a well-maintained and operated RO system could be an alternative to MAR. Pipeline systems which distribute good quality groundwater to nearby areas are another alternative drinking water option being increasingly invested in (Hoque et al. 2019). These systems are 
generally well accepted by the local population (Inauen et al. 2013). A well-functioning piped water supply system could be an alternative safe drinking water option, although installation and maintenance of piped systems is expensive, with costs increasing and quality decreasing with water transported over larger distances; furthermore, the provision of good quality deep groundwater through the pipelines may not be sustainable if the source is fossil groundwater pockets. Here it should be mentioned that the socio-economic diversity in the region was not considered, which was shown to vary (Johnson and Hutton 2018). In some parts, more expensive options could be feasible options; likewise, in poorer areas, MAR may be too expensive an option.

\section{Comparison of assessment with pilot MARs}

To assess the predictive value of the technical suitability map, it was compared with the observed performance of the pilot MAR sites. As the RE of the pilot MAR systems is not known because usually less is abstracted than was infiltrated, the quality of the abstracted water from the pilot MAR systems was used as an indicator of technical suitability. Unfortunately, this comparison is not without complications. An MAR system with an intrinsically low RE could be producing water of sufficient quality because much more water has been infiltrated than was abstracted. Similarly, an MAR system with a high RE could still produce water of insufficient quality at some moment if abstraction exceeds recharge. Nevertheless, this comparison was made, due to a lack of an alternative. There are 86 pilot MAR sites for which sufficient water quality data were available. The pilot sites are relatively evenly distributed across the first three technical suitability classes (Table 2): 20 in the class with a technical suitability lower than $0.5,33$ in the class with a technical suitability between 0.5 and 0.75 , and 27 in the class with a technical suitability between 0.75 and 1 ; however, there are only six pilot MAR sites in the class with a technical suitability of 1 .

For the comparison, it was first determined whether the MAR sites have ever been capable of producing water with an arsenic concentration and salinity within the Bangladesh drinking water standards. This was the case for 68 of the 86 MAR sites (Table 2). By comparison with the suitability classes, there is a slight tendency for observed performance to improve concomitantly with technical suitability (rising from 75 to $83 \%$ ) but the differences are not clearly visible. This reveals that the MAR sites have the potential to produce water of sufficient quality even in areas having a low technical suitability. However, this only reveals the initial performance of the MAR systems. The best water quality was typically reached at the onset of the dry season, when net abstraction starts to occur. Therefore, a second comparison was made with the status of the MAR sites after they had been in operation for a longer time period and after the dry season. Here, it was determined whether the MAR systems were still producing water of sufficient quality at 20 June 2016 (towards the end of the dry season in 2016). The results show that only 30 of the 86 pilot MAR sites still delivered water of sufficient quality, indicating that producing water of sufficient quality over longer time and throughout the dry season is more challenging for the pilot MAR sites. There are no clear differences between the technical suitability classes, as MAR sites in all classes perform worse than before, except the MAR sites with a technical suitability score of 1 . The latter score may be an indication of the predictive value of at least the class of best hydrogeological suitability.

The general lack of a clear relationship between the suitability index and the recorded performance of the pilot MAR sites suggests there are other factors that control the quality of the produced pilot MAR water. A more detailed assessment of the performance of the pilot MAR sites is recommended by determining the RE of the different pilot MAR sites. For a proper comparison, sites that have not operated continuously should be excluded.

\section{Conclusion}

This study aimed to reveal the potential for MAR in a region with brackish/saline and arsenic contaminated groundwater. The regional spatial distributions of the social necessity and technical suitability for MAR were combined, using the largest compiled groundwater quality dataset of southwestern Bangladesh to date, containing 3,716 salinity measurements and 827 arsenic data points.

The protected Sundarbans and the often-inundated areas (containing aquaculture and (tidal) river floodplains) largely limit areas where MAR systems can be installed. In areas with brackish groundwater or arsenic content above drinking water standards, MAR systems are expected to function technically well, but for implementation, it is recommended to evaluate centrally run instead of community-run MAR systems. In the saline southern parts of the region, where pond water is likely to be consumed, the community-run MAR systems are more likely to be adopted, but for implementation it is recommended to evaluate the MAR design and to construct MAR systems with a high infiltration rate to limit impacts of density-driven flow and MAR water quality deterioration. The calculated density-driven flow can be translated into a practical guideline for infiltration rate needed to achieve the approximate MAR infiltration rate that ensures sufficiently high recovery efficiencies.

Compared to the commonly used expert judgement methods, the approach of this study has advantages: (1) it is transparent and verifiable and (2) it provides practical insight into where MAR is needed and how successful implementation of MAR systems could be facilitated. Therefore, the results are 
valuable for designing a regional strategy for MAR implementation in southwestern Bangladesh. The approach may be useful for mapping MAR potential based on social necessity and technical suitability in other deltas worldwide having poor water quality with respect to salinity and/or arsenic.

Acknowledgements We would like to thank Chelsea Peters, Steven Goodbred and John Ayers from Vanderbilt University for allowing us to use their data on the region. Additionally, we would like to acknowledge the help of all the staff from the Delta-MAR office in Khulna, particularly Abir Delwaruzzaman, for their support during the fieldwork campaigns.
Funding information This work is part of the Delta-MAR project funded by the Urbanising Deltas of the World (UDW) programme of the Dutch Research Council (NWO-WOTRO) (Grant number: OND1357179).

\section{Compliance with ethical standards}

Declaration of competing interest The authors declare that they have no known competing financial interests or personal relationships that could have appeared to influence the work reported in this paper.

\section{Appendix}

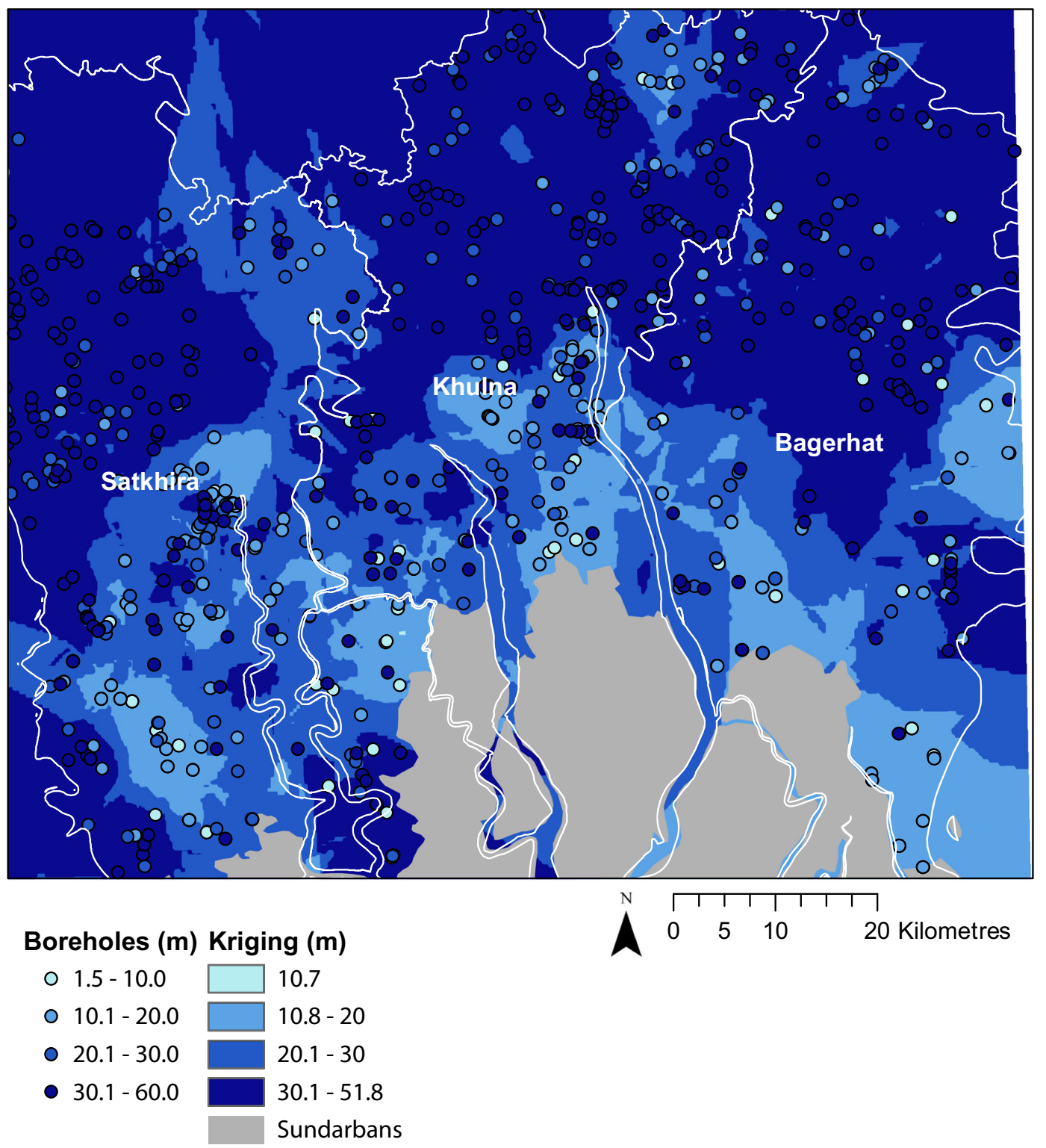

Fig. 10 Kriging results of the thickness of the largest continuous sand layer in the aquifer within the first $60 \mathrm{~m}$ 
Fig. 11 Kriging maps showing the electrical conductivity (EC) of a shallow, $\mathbf{b}$ intermediate deep, and $\mathbf{c}$ deep groundwater, and $\mathbf{d}$ arsenic concentration of shallow to intermediate deep groundwater

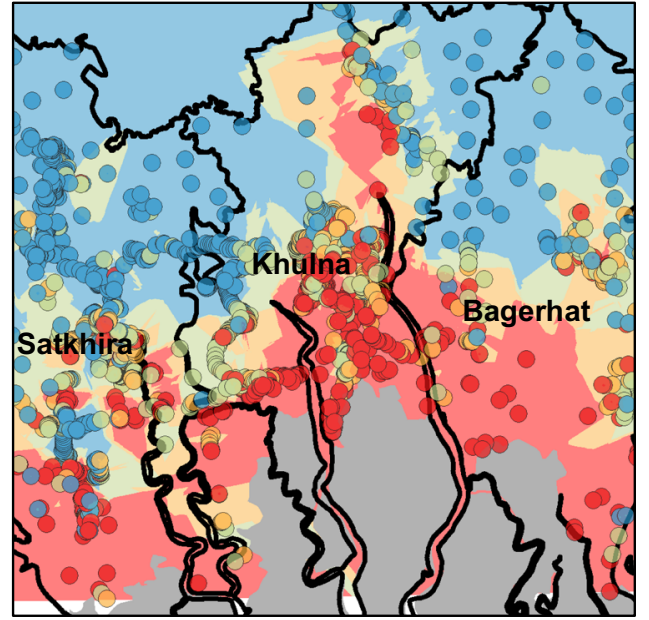

a) EC 0 - $60 \mathrm{~m}$

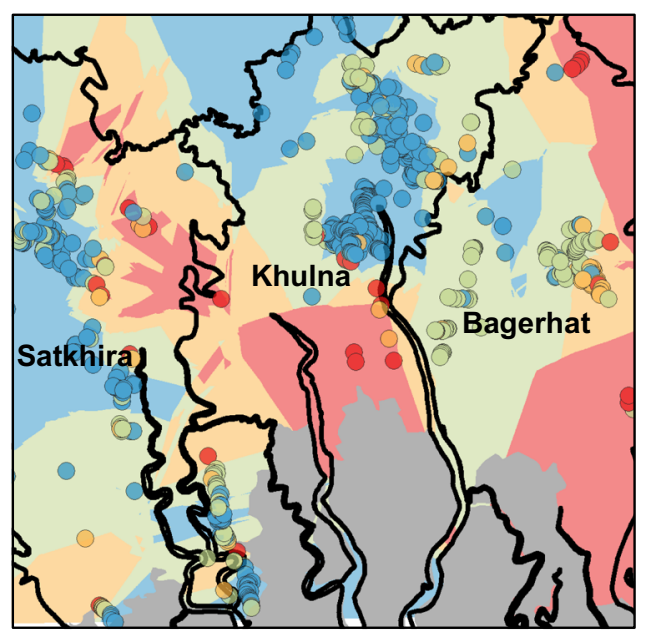

c) EC $100+m$

Legend

Measurements Kriging

$\mathrm{EC}(\mathrm{mS} / \mathrm{cm})$

○ $0.22-2.00$

○ $2.01-3.50$

- $3.51-5.00$

- $5+$

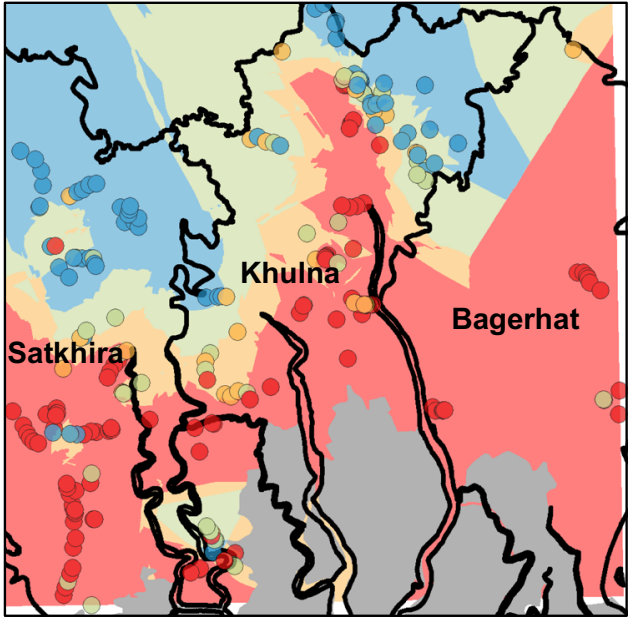

b) EC $60-100 \mathrm{~m}$

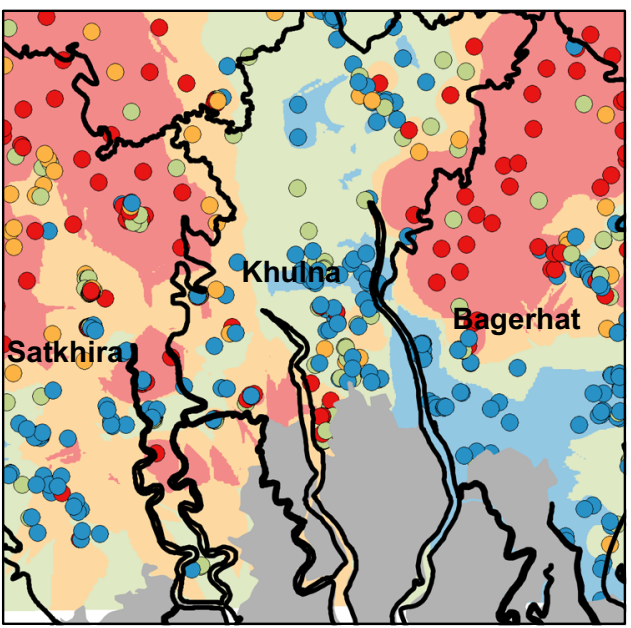

d) Arsenic 0 - $100 \mathrm{~m}$

\section{$\Lambda^{N} 1050 \quad 10$ Kilometres}

Open Access This article is licensed under a Creative Commons Attribution 4.0 International License, which permits use, sharing, adaptation, distribution and reproduction in any medium or format, as long as you give appropriate credit to the original author(s) and the source, provide a link to the Creative Commons licence, and indicate if changes were made. The images or other third party material in this article are included in the article's Creative Commons licence, unless indicated otherwise in a credit line to the material. If material is not included in the article's Creative Commons licence and your intended use is not permitted by statutory regulation or exceeds the permitted use, you will need to obtain permission directly from the copyright holder. To view a copy of this licence, visit http://creativecommons.org/licenses/by/4.0/.

\section{References}

Acacia Water (2014a) Technical report no. Manual for MAR system implementation in saline areas. Acacia Water, Gouda, The Netherlands, $6 \mathrm{pp}$

Acacia Water (2014b) Testing and evaluation of MAR system performance. Technical report, Acacia Water, Gouda, The Netherlands, 4 pp

Ayers JC, Goodbred S, George G, Fry D, Benneyworth L, Hornberger G, Roy K, Karim MR, Akter F (2016) Sources of salinity and arsenic in groundwater in southwest Bangladesh. Geochem Trans 17:4. https:// doi.org/10.1186/s12932-016-0036-6

Ayers JC, George G, Fry D, Benneyworth L, Wilson C, Auerbach L, Roy K, Karim MR, Akter F, Goodbred S (2017) Salinization and arsenic 
contamination of surface water in southwest Bangladesh. Geochem Trans 18:4. https://doi.org/10.1186/s12932-017-0042-3

Bakker M (2010) Radial Dupuit interface flow to assess the aquifer storage and recovery potential of saltwater aquifers. Hydrogeol J 18: 107-115. https://doi.org/10.1007/s10040-009-0508-1

Bangladesh Bureau of Statistics (2011) Population and housing census 2011: socio-economic and demographic report, National Series, vol 4. Statistics and Informatics Division, Ministry of Planning

Bangladesh Water Development Board (2013) Hydrogeological study and mathematical modelling to identify sites for installation of observation well nests. Selection of model boundary, supervision of pumping test, slug test, assessment of different hydrogeological parameters collection and conduct chemical analysis of surface water and groundwater (Package-3). Government of the People's Republic of Bangladesh, Ministry of Water Resources, Dhaka

Barker JLB, Hassan MM, Sultana S, Ahmed KM, Robinson CE (2016) Numerical evaluation of community-scale aquifer storage, transfer and recovery technology: A case study from coastal Bangladesh. J Hydrol 540:861-872

Benneyworth L, Gilligan J, Ayers J, et al (2016) Drinking water insecurity: water quality and access in coastal south-western Bangladesh. Int J Environ Health Res 26:5-6:508-524. https://doi.org/10.1080/ 09603123.2016 .1194383

Bhuiyan MJAN, Dutta D (2012) Assessing impacts of sea level rise on river salinity in the Gorai River network, Bangladesh. Estuar Coast Shelf Sci 96:219-227. https://doi.org/10.1016/j.ecss.2011.11.005

Borgomeo E, Hall JW, Salehin M (2018) Avoiding the water-poverty trap: insights from a conceptual human-water dynamical model for coastal Bangladesh. Int J Water Resour Dev 34:900-922. https://doi. org/10.1080/07900627.2017.1331842

British Geological Survey (BGS) and Department of Public Health Engineering (DPHE) (2001) Arsenic contamination of groundwater in Bangladesh. BGS technical report WC/00/19, British Geological Survey, Keyworth, UK

Brown CJ, Weiss R, Verrastro R, Schubert S (2005) Development of an aquifer, storage and recovery (ASR) site selection suitability index in support of the Comprehensive Everglades Restoration Project. J Environ Hydrol 13(20):1-13

Chowdhury NT (2010) Water management in Bangladesh: an analytical review. Water Policy 12:32. https://doi.org/10.2166/wp.2009.112

Chowdhury A, Jha MK, Chowdary VM (2009) Delineation of groundwater recharge zones and identification of artificial recharge sites in West Medinipur district, West Bengal, using RS, GIS and MCDM techniques. Environ Earth Sci 59:1209-1222. https://doi.org/10. 1007/s12665-009-0110-9

Despins C, Farahbakhsh K, Leidl C (2009) Assessment of rainwater quality from rainwater harvesting systems in Ontario, Canada. J Water Supply Res Technol - AQUA 58:117-134. https://doi.org/ 10.2166/aqua.2009.013

Dillon P (2005) Future management of aquifer recharge. Hydrogeol J 13: 313-316. https://doi.org/10.1007/s10040-004-0413-6

Dobrowsky PH, De Kwaadsteniet M, Cloete TE, Khan W (2014) Distribution of indigenous bacterial pathogens and potential pathogens associated with roof-harvested rainwater. Appl Environ Microbiol 80:2307-2316. https://doi.org/10.1128/aem.04130-13

Fendorf S, Michael HA, Van Geen A (2010) Spatial and temporal variations of groundwater arsenic in South and Southeast Asia. Science 382(5982):1123-1127

Flanagan S, Johnston R, Zheng Y (2012) Arsenic in tube well water in Bangladesh: health and economic impacts and implications for arsenic mitigation. Bull World Health Org 90:839-846. https://doi. org/10.2471/BLT.11.101253

Fofonoff NP, Millard RCJ (1983) Algorithms for the computation of fundamental properties of seawater. UNESCO Technical Papers in Marine Sciences 44, UNESCO, Paris
Ghayoumian J, Mohseni Saravi M, Feiznia S, Nouri B, Malekian A (2007) Application of GIS techniques to determine areas most suitable for artificial groundwater recharge in a coastal aquifer in southern Iran. J Asian Earth Sci 30:364-374. https://doi.org/10.1016/j.jseaes.2006.11.002

Harvey CF, Swartz CH, Badruzzaman ABM, Keon-Blute N, Yu W, Ali MA, Jay J, Beckie R, Niedan V, Brabander D, Oates PM, Ashfaque KN, Islam S, Hemond HF, Ahmed MF (2002) Arsenic mobility and groundwater extraction in Bangladesh. Science 298:1602-1606. https://doi.org/10.1126/science.1076978

Hasan MM, Ahmed KM, Sultana S, Rahman MS, Ghosh SK, Ravenscroft P (2018) Investigations on groundwater buffering in Khulna-Satkhira Coastal Belt using managed aquifer recharge. In: Mukherjee A (ed) Groundwater of South Asia. Springer, Singapore

Hasan MB, Driessen PPJ, Majumder S, Zoomers A, Van Laerhoven F, (2019) Factors affecting consumption of water from a newly introduced safe drinking water system: the case of managed aquifer recharge (MAR) systems in Bangladesh. Water 11(12):2459. https:// doi.org/10.3390/w11122459

Hoque MA, Hoque MM, Ahmed KM (2007) Declining groundwater level and aquifer dewatering in Dhaka metropolitan area, Bangladesh: causes and quantification. Hydrogeol J 15:15231534. https://doi.org/10.1007/s10040-007-0226-5

Hoque SF, Hope R, Arif ST, Akhter T, Naz M, Salehin M (2019) A socialecological analysis of drinking water risks in coastal Bangladesh. Sci Total Environ 679:23-34. https://doi.org/10.1016/j.scitotenv.2019.04. 359

Horneman A, van Geen A, Kent DV, Mathe PE, Zheng Y, Dhar RK, O'Connell S, Hoque MA, Aziz Z, Shamsudduha M, Seddique AA, Ahmed KM (2004) Decoupling of as and Fe release to Bangladesh groundwater under reducing conditions, part I: evidence from sediment profiles. Geochim Cosmochim Acta 68:3459-3473. https:// doi.org/10.1016/j.gca.2004.01.026

Inauen J, Hossain MM, Johnston RB, Mosler HJ (2013) Acceptance and use of eight arsenic-safe drinking Water options in Bangladesh. PLoS One 8:e53640. https://doi.org/10.1371/journal.pone.0053640

Islam MM, Chou FNF, Kabir MR, Liaw CH (2010) Rainwater: a potential alternative source for scarce safe drinking and arsenic contaminated water in Bangladesh. Water Resour Manag 24:3987-4008. https://doi.org/10.1007/s11269-010-9643-7

Islam MA, Sakakibara H, Karim MR, Sekine M, Mahmud ZH (2011) Bacteriological assessment of drinking water supply options in coastal areas of Bangladesh. J Water Health 9:415-428. https:// doi.org/10.2166/wh.2011.114

Islam MA, Akber MA, Ghosh PK (2018) Water quality of small-scale desalination plants in southwest coastal Bangladesh. Water Supply 18(5):1606-1616. https://doi.org/10.2166/ws.2017.222

Johnson FA, Hutton CW (2018) A Geospatial Analysis of the Social, Economic and Environmental Dimensions and Drivers of Poverty in South-West Coastal Bangladesh. In Ecosystem Services for WellBeing in Deltas. Palgrave Macmillan, Cham, pp 383-403

Kabir MP, Islam MA, Akber MA, Ahsan MS (2016) Bacteriological assessment of aquifer storage and recovery (ASR) water in southwest coastal Bangladesh. J Water Sanit Hygiene Dev 6:231-241. https://doi.org/10.2166/washdev.2016.171

Kallali H, Anane M, Jellali S, Tarhouni J (2007) GIS-based multi-criteria analysis for potential wastewater aquifer recharge sites. Desalination 215:111-119. https://doi.org/10.1016/j.desal.2006.11.016

Khan AE, Scheelbeek PFD, Shilpi AB, Chan Q, Mojumder SK, Rahman A, Haines A, Vineis P (2014) Salinity in drinking water and the risk of (pre)eclampsia and gestational hypertension in coastal Bangladesh: a case-control study. PLoS One 9:e108715. https:// doi.org/10.1371/journal.pone.0108715

Knappett PSK, Escamilla V, Layton A, McKay LD, Emch M, Williams DE, Huq R, Alam J, Farhana L, Mailloux BJ, Ferguson A, Sayler GS, Ahmed KM, van Geen A (2011) Impact of population and latrines on 
fecal contamination of ponds in rural Bangladesh. Sci Total Environ 409:3174-3182. https://doi.org/10.1016/j.scitotenv.2011.04.043

Kränzlin I (2000) Pond management in rural Bangladesh: problems and possibilities in the context of the water supply crisis. Nat Resour Forum 24:211-223. https://doi.org/10.1111/j.1477-8947.2000. tb00945.x

Lowry CS, Anderson MP (2006) An assessment of aquifer storage recovery using ground water flow models. Ground Water 44:661-667. https://doi.org/10.1111/j.1745-6584.2006.00237.x

Maliva RG, Guo W, Missimer TM (2006) Aquifer storage and recovery: recent hydrogeological advances and system performance. Water Environ Res 78:2428-2435. https://doi.org/10.2175/ 106143006X123102

Mukherjee A, Fryar AE, Thomas WA (2009) Geologic, geomorphic and hydrologic framework and evolution of the Bengal basin, India and Bangladesh. J Asian Earth Sci 34:227-244. https://doi.org/10.1016/ j.jseaes.2008.05.011

Naus FL, Schot P, Groen K, Ahmed KM, Griffioen J (2019a) Groundwater salinity variation in Upazila Assasuni (southwestern Bangladesh), as steered by surface clay layer thickness, relative elevation and present-day land use. Hydrol Earth Syst Sci 23: 1431-1451. https://doi.org/10.5194/hess-23-1431-2019

Naus FL, Schot P, Ahmed KM, Griffioen J (2019b) Influence of landscape features on the large variation of shallow groundwater salinity in southwestern Bangladesh. J Hydrol X 5:100043. https://doi.org/ 10.1016/j.hydroa.2019.100043

Naus FL, Burer K, van Laerhoven F, Griffioen J, Ahmed KM, Schot P (2020) Why do people remain attached to unsafe drinking Water options? Quantitative evidence from southwestern Bangladesh. Water 12(2):342

Nickson R, McArthur J, Burgess W, Ahmed KM, Ravenscroft P, Rahmanñ M (1998) Arsenic poisoning of Bangladesh groundwater. Nature 395:338-338. https://doi.org/10.1038/26387

Ning RY (2002) Arsenic removal by reverse osmosis. Desalination 143: 237-241. https://doi.org/10.1016/S0011-9164(02)00262-X

Nizame F, Nizame FA, Naser M, Sharmin A, Jahir T, Doza S, Rahman M, Unicomb L (2020) Community finance and promotion of managed aquifer recharge systems affect uptake and sustainability as a potable water source in southwest coastal Bangladesh: a qualitative study. (Under review) https://doi.org/10.21203/rs.2.20647/v1

Peters CN, Baroud H, Hornberger GM (2019) Multicriteria decision analysis of drinking water source selection in southwestern Bangladesh. J Water Resour Plan Manag 145:05019004. https://doi.org/10.1061/ (ASCE)WR.1943-5452.0001029

Post VEA (2012) Electrical conductivity as a proxy for groundwater density in coastal aquifers. Ground Water 50:785-792. https://doi. org/10.1111/j.1745-6584.2011.00903.x

Rahman MA, Rusteberg B, Gogu RC, Lobo Ferreira JP, Sauter M (2012) A new spatial multi-criteria decision support tool for site selection for implementation of managed aquifer recharge. J Environ Manag 99:61-75. https://doi.org/10.1016/j.jenvman.2012.01.003

Rahman M, Bakker M, Patty L, Hassan Z, Röling W, Ahmed KM, van Breukelen BM (2015) Reactive transport modeling of subsurface arsenic removal systems in rural Bangladesh. Sci Total Environ 537:277-293

Rahman AKMM, Ahmed KM, Butler AP, Hoque AM (2018) Influence of surface geology and micro-scale land use on the shallow subsurface salinity in deltaic coastal areas: a case from Southwest Bangladesh. Environ Earth Sci 77:423. https://doi.org/10.1007/ s12665-018-7594-0

Ravenscroft P, Burgess WG, Ahmed KM, Burren M, Perrin J (2005) Arsenic in groundwater of the Bengal Basin, Bangladesh: distribution, field relations, and hydrogeological setting. Hydrogeol J 13: 727-751. https://doi.org/10.1007/s10040-003-0314-0

Russo TA, Fisher AT, Lockwood BS (2015) Assessment of managed aquifer recharge site suitability using a GIS and modeling. Groundwater 53:389-400. https://doi.org/10.1111/gwat.12213
Saraf AK, Choudhury PR (1998) Integrated remote sensing and GIS for groundwater exploration and identification of artificial recharge sites. Int J Remote Sens 19:1825-1841. https://doi.org/10.1080/ 014311698215018

Shahid S, Hazarika MK (2010) Groundwater drought in the northwestern districts of Bangladesh. Water Resour Manag 24:1989-2006. https://doi.org/10.1007/s11269-009-9534-y

Shameem MIM, Momtaz S, Rauscher R (2014) Vulnerability of rural livelihoods to multiple stressors: a case study from the southwest coastal region of Bangladesh. Ocean Coast Manag 102:79-87. https://doi.org/10.1016/j.ocecoaman.2014.09.002

Sharma B, Amarasinghe U, Xueliang C, de Condappa D, Shah T, Mukherji A, Bharati L, Ambili G, Qureshi A, Pant D, Xenarios S, Singh R, Smakhtin V (2010) The Indus and the Ganges: river basins under extreme pressure. Water Int 35:493-521. https://doi.org/10. 1080/02508060.2010.512996

Sprenger C, Hartog N, Hernández M, Vilanova E, Grützmacher G (2017) Inventory of managed aquifer recharge sites in Europe: historical development, current situation and perspectives. Hydrogeol J 25(6):1909-1922

Stefan C, Ansems N (2018) Web-based global inventory of managed aquifer recharge applications. Sustain Water Resour Manag 4: 153-162. https://doi.org/10.1007/s40899-017-0212-6

Sultana S, Ahmed KM, Mahted-Ul-Alam SM, Hasan M, Tuinhof A, Ghosh SK, Rahman MS, Ravenscroft P, Zheng Y (2015) Lowcost aquifer storage and recovery: implications for improving drinking Water access for rural communities in coastal Bangladesh. J hydrol Eng 20(3):B5014007

United Nations (2015) General Assembly Resolution 70/1, Transforming Our World: The 2030 Agenda for Sustainable Development. http:// undocs.org/en/A/RES/70/1

van Halem D, Olivero S, de Vet WWJM, Verberk JQJC, Amy GL, van Dijk JC (2010) Subsurface iron and arsenic removal for shallow tube well drinking water supply in rural Bangladesh. Water Res 44: 5761-5769. https://doi.org/10.1016/j.watres.2010.05.049

Ward JD, Simmons CT, Dillon PJ, Pavelic P (2009) Integrated assessment of lateral flow, density effects and dispersion in aquifer storage and recovery. J Hydrol 370:83-99. https://doi.org/10.1016/j.jhydrol. 2009.02.055

Worland SC, Hornberger GM, Goodbred SL (2015) Source, transport, and evolution of saline groundwater in a shallow Holocene aquifer on the tidal deltaplain of southwest Bangladesh. Water Resour Res 51:5791-5085. https://doi.org/10.1002/2015WR017198.A

Yokota H, Tanabe K, Sezaki M, Akiyoshi Y, Miyata T, Kawahara K, Tsushima S, Hironaka H, Takafuji H, Rahman M, Ahmad SA, Sayed MHSU, Faruquee MH (2001) Arsenic contamination of ground and pond water and water purification system using pond water in Bangladesh. Eng Geol 60:323-331. https://doi.org/10. 1016/S0013-7952(00)00112-5

Zaman AM, Molla MK, Pervin IA, Rahman SMM, Haider AS, Ludwig F, Franssen W (2017) Impacts on river systems under $2{ }^{\circ} \mathrm{C}$ warming: Bangladesh case study. Clim Serv 7:96-114. https://doi.org/10. 1016/j.cliser.2016.10.002

Zuurbier KG, Bakker M, Zaadnoordijk WJ, Stuyfzand PJ (2013) Identification of potential sites for aquifer storage and recovery (ASR) in coastal areas using ASR performance estimation methods. Hydrogeol J 21:1373-1383. https://doi.org/10.1007/s10040-013-1003-2

Zuurbier KG, Zaadnoordijk WJ, Stuyfzand PJ (2014) How multiple partially penetrating wells improve the freshwater recovery of coastal aquifer storage and recovery (ASR) systems: a field and modeling study. J Hydrol 509:430-441. https://doi.org/10.1016/j.jhydrol.2013.11.057

Publisher's note Springer Nature remains neutral with regard to jurisdictional claims in published maps and institutional affiliations. 